This PDF is a selection from a published volume from the National Bureau of Economic Research

Volume Title: Europe and the Euro

Volume Author/Editor: Alberto Alesina and Francesco Giavazzi, editors

Volume Publisher: The University of Chicago Press

Volume ISBN: 0-226-01283-2

Volume URL: http://www.nber.org/books/ales08-1

Conference Dates: October 17-18, 2008

Publication Date: February 2010

Chapter Title: The Estimated Trade Effects of the Euro: Why Are They Below Those from Historical Monetary Unions among Smaller Countries?

Chapter Author: Jeffrey Frankel

Chapter URL: http://www.nber.org/chapters/c11658

Chapter pages in book: (169- 212) 


\title{
The Estimated Trade Effects of the Euro \\ Why Are They Below Those from \\ Historical Monetary Unions among Smaller Countries?
}

\author{
Jeffrey Frankel
}

Andrew Rose's 2000 paper, "One Money, One Market: Estimating the Effect of Common Currencies on Trade," was perhaps the most influential international economics paper of the last ten years. Applying the gravity model to a data set that was sufficiently large to encompass a number of currency unions led to an eye-opening finding: members of currency unions traded with each other an estimated three times as much as with otherwise similar trading partners. Even if Rose had not included the currency union dummy, his paper would still have been important, because he had bilateral exchange rate variability on the list of variables explaining bilateral trade, and it was highly significant statistically. ${ }^{1}$ But the attention grabber was that the currency union dummy had a far larger and highly significant effect - the famous tripling estimate - above and beyond the effect of bilateral variability per se. The Rose paper was of course motivated by the coming of the European Monetary Union (EMU) in 1999, even though estimates were necessarily based on historical data from (much smaller) countries that had adopted currency unions in the past.

Jeffrey Frankel is the James W. Harpel Professor of Capital Formation and Growth at the John F. Kennedy School of Government, Harvard University, and a research associate of the National Bureau of Economic Research.

The author wishes to thank Francesco Giavazzi, Ernesto Stein, and Sylvana Tenreyo for comments and Clara Zverina for research assistance.

1. The finding that a fixed exchange rate in itself also produces a statistically significant increase in bilateral trade has more recently been confirmed by Klein and Shambaugh (2006). 


\subsection{First Post-1999 Results on Effects of the Euro on European Trade Patterns}

By roughly the five-year mark, 2004, enough data had accumulated to allow an analysis of the early effects of the euro on European trade patterns. The general finding was that bilateral trade among euro members had indeed increased significantly but that the effect was far less than the one that had been estimated by Rose on the larger data set of smaller countries. Micco, Stein, and Ordoñez (MSO; 2003) found in a data set of European countries that trade between pairs of the first twelve EMU joiners rose significantly between 1999 and 2002, an estimated 15 percent beyond what could be explained by growth and other factors. The estimates of the euro effect in a larger set of twenty-two industrialized countries ranged from 6 to 26 percent, depending on dummies. The authors expressed a preference for estimates that allowed for pair dummies and produced a somewhat smaller estimate of the effect: 4 to 16 percent. $^{2}$ These magnitudes were less than in the Rose studies. As the authors pointed out, however, the effects were both statistically significant and also economically important, which is not bad, considering that the sample covered only the first four years of the EMU, a period in which the euro did not even circulate in currency form.

Other evidence from the first five years confirmed the finding. Bun and Klaassen $(2002,1)$ updated gravity estimates and found that "the euro has significantly increased trade, with an effect of $4 \%$ in the first year" and a long-run effect projected to be about 40 percent. Flam and Nordström (2006) found an effect of 26 percent in the change from 1995 through 1998 to 2002 through 2005. Berger and Nitsch (2005) and De Nardis and Vicarelli (2003) reported similarly positive results. More recently, Chintrakarn (2008) finds that two countries sharing the euro have experienced a boost in bilateral trade between 9 and 14 percent. Overall, the central tendencies of these estimates seem to be an effect in the first few years on the order of 10 to 15 percent. $^{3}$

Thus, the trade effects of monetary union are not entirely limited to small countries. But they are far smaller than the tripling estimated by Rose. The central questions of this chapter are (a) what are the estimated effects,

2. Earlier, the preferred Micco, Stein, and Ordoñez (2002) estimates of "differences in differences" showed that between 1992 and 2001, the boost to intra-EMU trade was about 18 to 35 percent, depending on whether using country-pair dummies or conditioning on the standard gravity variables.

3. Studies with price data have tended to be more mixed, but some confirm that the euro is facilitating arbitrage among the markets of member countries. Looking at price data across pairs of European cities, Rogers $(2001,2002)$ finds evidence of convergence-but in the 1990s. In the European auto market, Goldberg and Verboven (2001) find gradual convergence over the period from 1970 to 2000. Goldberg and Verboven (2004) nail down EMU per se as a significant determinant of this convergence. Other positive findings come from Allington, Kattuman, and Waldman (2005) and Parsley and Wei (2001). Engel and Rogers (2004) are more negative. 
updated at the ten-year mark, and (b) assuming they are similar to the 10 to 15 percent effects estimated by the early studies of euroland, what explains the large gap between the euro estimates and the tripling effects estimated by Rose and others using much larger historical data sets? Is it a matter of lags so that the 10 to 15 percent can be expected to rise gradually over time, eventually reaching levels comparable with those estimated for currency unions that have been around for one hundred years? Or is the currency union effect systematically smaller for large countries than for small countries? Or, is the tripling among the smaller countries merely an artifact of estimation problems associated with endogeneity and omitted variables? Finally, is there some effect (or lack thereof) peculiar to Europe?

\subsection{The Critiques}

Rose's remarkable tripling estimate has by now been replicated in various forms many times. But no sooner had he written his paper than the brigade to "shrink the Rose effect"4 — or to make it disappear altogetherdescended en masse. These critiques sometimes read to me as "guilty until proven innocent."

It is understandable that a threefold effect was greeted with much skepticism, as this is a very large number. There are five grounds for skepticism, as I classify them. Each of these arguments is potentially potent in the context of assessing the euro's effect on European trade patterns, if for no other reason than the claims that the Rose finding has always been spurious. But the critiques need to be assessed.

The first critique is the proposition that one cannot necessarily infer from cross-sectional evidence what would be the effect in real time of countries adopting a common currency. Most pre-1999 members of currency unions had essentially never had their own national currencies but instead used an external currency, at least since independence. In such cases as Panama or most of the Communaute Financière d'Afrique (CFA) countries in Africa, the currency arrangement goes back more than a century. In other cases, such as the Eastern Caribbean currency area, the currency dates from postwar independence.

Second are allegations of missing variables. The statistical association between currency links and trade links might not be the result of causation running from currencies to trade but might arise instead because both sorts of links are caused by a third factor, such as colonial history, remaining political links, complementarity of endowments, or accidents of history.

4. The phrase is from Richard Baldwin (2006). Baldwin's survey of the critiques concludes in the end that there is a Rose effect but that it is probably substantially smaller than a tripling. That is fine with me. If Rose had come up with a 50 percent effect on trade from the beginning, everyone would have considered that very large and important. 
Another alleged missing variable is a country's "multilateral resistance" to trade or a more specific measure of remoteness from the rest of the world.

The third critique also concerns causality: the endogeneity of the currency decision. Countries choose as partners for currency links the neighbors with whom they trade the most rather than the other way around. Perhaps the endogeneity of the currency union decision and the simultaneity of other regional trade-promoting forces have been stronger among developing countries than among European countries. In other words, much of the correlation observed for currency unions among other countries may be spurious.

Fourth, the estimated effect on trade simply seems too big to be believable. While this judgment is explicitly a gut reaction, it is widely shared. Furthermore, an influential argument by Van Wincoop to the effect that the question has been misparameterized and that the true effects are substantially smaller seems to support it.

Fifth, Rose's evidence came entirely from countries that were either small (e.g., Ireland, Panama) or very small (e.g., Kiribati, Greenland, Mayotte). Thus, it was not clear that the estimates could be extended to larger countries. European economies tend to be large - some, particularly Germany, very large - while the set of non-EMU currency union countries tends to be small - some of them very small. If the currency union effect is substantially more important in small, highly trade-dependent countries, that could readily explain the small estimates for Europe.

While each of these five arguments has some validity, to each there is a better response than one might expect.

\subsubsection{Times Series Dimension}

First, regarding the time dimension, a logical interpretation is that even if the full comparative statics effect were to obtain in the very long run after a change in regime, they might not show up in the short run due to very substantial lags. That would not be surprising, as we have evidence of long lags in effects on bilateral trade.

Even thirty years may not be the long-run effect. The effect may keep rising for a long time. Panama reports sending more than half its exports to the United States; perhaps one reason is that it has been on the U.S. dollar for over one hundred years.

We know that other gravity influences leave an effect on bilateral trade many decades after the cause has been removed. One piece of evidence is the generally slow speed of adjustment estimated in models with lags. ${ }^{5}$ Another important example is the effect that colonial relationships have, even decades after independence, and even after controlling for continu-

5. Eichengreen and Irwin (1998). Frankel (1997) discusses lagged effects historically for the cases of FTAs and political unions. 
ing linguistic, political, or other links. Consider as an illustration a trivia question: what is Congo's largest trading partner? Not one of its neighbors, nor a large country, as the simple gravity model would lead you to expect; it is Belgium, the old colonial master, with whom ties were abruptly severed fifty years ago. ${ }^{6}$ Even when the original reason for a high level of bilateral trade has disappeared, the stock of capital that firms have invested in the form of marketing and distribution networks, brand-name loyalty among customers, and so forth, lives on for many years thereafter. The word hysteresis is sometimes applied to this phenomenon, suggesting that the effect is considered to be permanent.

Subsequent research on currency unions using time series data finds that a substantial share of the tripling that Rose had estimated from the crosssectional data, which is presumably the long-run effect, shows up within a few decades of a change. Using a 1948 to 1997 sample that includes a number of countries that left currency unions during that period, Glick and Rose (2002) find that trade among the members was twice as high in the currency union period as afterward. This suggests that roughly two-thirds of the tripling effect may be reached within three decades of a change in regime. (This reasoning assumes symmetry with respect to entry into and exit from currency unions.)

\subsubsection{Omitted Variables}

The second objection concerns the possible influence of omitted factors. Rose in fact did a thorough job of controlling for common languages, colonial history, and remaining political links. ${ }^{7}$ The large estimated effect of a common currency remains. It seems very possible that there remain other omitted factors (including accidents of history) that influence both currency choices and trade links. Nevertheless, Rose's various extensions of the original research - these robustness tests, together with the time series results (Glick and Rose 2002) and the common use of fixed effects-reduce some of the force of this critique.

The omitted variable that is probably of greatest concern to the critics comes from the influential Anderson and Van Wincoop (2001) paper and is usually called "multilateral resistance term." "More concretely, in a cross-

6. Kleiman (1976) finds that about one-quarter of the (two- to four-fold) bias of colonial times remains for countries that have been independent for two decades. Anderson and Norheim (1993) find longer lags in the effects of colonial status. Wang and Winters (1991) and Hamilton and Winters (1992) find significant effects for UK excolonial relationships (though not French) as late as 1984 to 1986.

7. While it is admirable how many factors Rose controls for, I agree with Baldwin (2006) and also Melitz (2001) in regarding as a "nuisance" Rose's persistent habit of calling these "nuisance parameters." These coefficients are of interest in their own right and also help to gauge the persuasiveness of the overall model.

8. Baldwin wants to call it the "relative prices matter" term. It could also be called the "general equilibrium" term. 
sectional context, the variable may come down to "remoteness." A country's remoteness is defined as the average distance from all trading partners, a weighted average based on the sizes of the trading partners; it is expected to have a positive effect on trade between a pair of countries, controlling for the more obvious negative effect of the distance between them bilaterally. The authors are a bit fanatical on this point: anyone who omits the relevant terms is not fit to be received in polite society. ${ }^{9}$

The Anderson and Van Wincoop (2001) model is an important contribution, both in serving as a theoretical foundation for the gravity model and in offering an argument that some of the border effects may have been quantitatively overestimated. Rose and Van Wincoop (2001) find that taking multilateral resistance and trade diversion into account should a priori knock the estimated value of the euro on bilateral trade down from tripling to 58 percent (among the original euro members). But the model's insistence on the role of trade diversion may be too doctrinaire. If I understand correctly the aspect of the Anderson and Van Wincoop theory that leads to numerical estimates of the effects of borders and currencies that are sharply reduced in magnitude, it is the property that the elimination of borders or currency differences within a region theoretically entails substantial diversion of trade away from the rest of the world and thus an increase in multilateral resistance. But such trade diversion from currency unions, whatever its basis in theory, is not observed in the data, by and large. ${ }^{10}$ Thus, the argument for imposing the constraints from this particular theory may not be as strong as it otherwise would be. Furthermore, even if one goes along with Van Wincoop in imposing the constraint, the currency union term apparently remains high, (a) compared to its standard error, (b) compared to what we all thought ten years ago, and (c) compared to what happens to the free trade agreement (FTA) term when it too is knocked down by imposing the Van Wincoop constraint.

\subsubsection{Causality Problems}

The endogeneity of a country's choice of exchange regime is perhaps the most intractable problem with the Rose-style estimates. After all, optimum currency area theory suggests that countries should peg if they are small and open and should peg to the partners with whom they trade a lot. ${ }^{11} \mathrm{El}$

9. I am one of those who long ago included remoteness in some of my gravity estimates (though not all). I devoted two pages to the subject in Frankel $(1997,143-4)$ and noted that it sometimes makes a difference to the results. The resistance to Canadian-U.S. trade is an example of where it makes a difference: Wei (1996) found that controlling for remoteness helped knock down the home country bias from around 10 to around 3 . Another may be the finding of a huge apparent effect of Pacific Islanders adopting the Australian dollar in Nitsch (2001).

10. For example, the United Kingdom does not appear to have lost trade to euroland as a result of the euro; Begg et al. (2003), Frankel and Rose (2002), Frankel (2003), Micco, Stein, and Ordoñez (2003), and Chintrakarn (2008).

11. McKinnon (1963). Among many applications to Central and Eastern Europe is Frankel (2005). 
Salvador decided to adopt the dollar because it traded a lot with the United States rather than the other way around. In that case, the Rose finding would be spurious. Controlling for exogenous third factors such as colonial history is a partial correction but not a complete one, because they don't completely determine trade patterns.

One might reasonably ask why the same logic would not apply equally to the decisions by European countries to join the euro. Clearly, the countries that have been most firmly committed to European monetary integration from the beginning (say, Germany, the Netherlands, and Luxembourg) have been those that were the most thoroughly integrated with each other, anyway. Those that have stayed out tend to be those that are less integrated. If this is enough to produce a tripling in the context of other countries, why is the estimated correlation so low in Europe?

Many of the critiques of the Rose results, after pointing out a problem of omitted variables or endogeneity or one of the other legitimate problems, offer a purported way to address it and then report that the currency union effect disappears. ${ }^{12}$ My own view is that many of these responses effectively throw out most of the data in the name of addressing the (correctly emphasized) issues of endogeneity or country size. Or, they do something similar: put in a great many dummy variables or fixed effects, often one for every pair of countries. This approach seems these days to be considered not just good econometric practice, but essential; we are told that we are not allowed so much as a peek at evil studies that neglect to do this. But my view is that because the finding of statistical significance arose only when Rose put together a large enough data set for it to show up,,$^{13}$ there is not that much information gained in reducing the data set sharply and then noticing the loss in statistical significance. Most of the statistical power lies in the crosscountry variation. Throw that out, and one may be left with little.

That said, the complete bilateral data set is so large and the statistical relationship is so strong that there is some firepower to spare, and it is worth using some of it to try to get at the problems of endogeneity and missing variables. Including fixed effects for countries and/or years has become standard. The results generally hold up. Adding fixed effects for pairs of countries in the basic specification is a bit more problematic, though reasonable as a test for robustness. Rose (2001) himself tried adding pair-fixed effects to his original data set and found that the currency union dummy lost all significance, while he pointed out that it is hard to see how it could have been otherwise, as all the action is in the bilateral cross-section. The same was

12. See Rose (2001) for a reply to one, and for more, see his Web site, available at: http://faculty. haas.berkeley.edu/arose/RecRes.htm\#CUTrade.

13. Earlier gravity studies had not found major evidence of currency link effects on bilateral trade, presumably because the data sets were too small to include many examples of countries with institutionally fixed exchange rates: Thursby and Thursby (1987), De Grauwe (1988), Brada and Mendez (1985), and Frankel and Wei (1993, 1995a, 1995b, 1997). 
true with Pakko and Wall (2001). Klein (2002), who deliberately focuses on U.S. bilateral data alone, is one of many examples of throwing out enough data until the results become insignificant. Persson (2001) is another, despite the virtues of the matching estimator. When Rose tries Persson's matching estimator on a larger data set, he finds a significant (though smaller) effect (2.6.3).

More persuasive still is a before-and-after study such as that of Glick and Rose. It eliminates the problem that Panama has always (since independence) been on the dollar because it has always traded with the United States, much as Luxembourg has always had a currency union with Belgium (at least since the Latin Monetary Union of 1865) because it has always traded with Belgium. Rather, these results show that when a country enters or leaves a currency link, its bilateral trade responds accordingly. But none of this is to deny that endogeneity remains a likely problem. For example, an evolution in trade patterns may come first, with the currency decision following. In theory, Ireland may have switched its currency allegiance from Britain to the continent in response to shifting trade patterns rather than as a cause of them. Attempting to deal with the endogeneity problem should be a priority.

\subsubsection{Implausible Magnitude of the Estimate}

Fourth, although those who claim that the tripling number is too large to sound plausible have a point, they tend to neglect two counterarguments. In the first place, the estimated effect of currency unions is on the same order of magnitude as the estimated effects of FTAs, or if anything is larger. ${ }^{14}$ When one applies some of the variant estimation strategies, such as the Rose and Van Wincoop reparameterization, so that the estimated effect of currency unions falls, the estimated effects of regional trading arrangements tend to fall in tandem. The point estimates, significance levels, and necessary methodological qualifications are comparable across the two kinds of unions: FTAs and currency unions. In the second place, the estimated effects of currency unions are almost as big as the famous estimated effects of borders (home bias) - for example, in the Canadian-U.S. context, which is at least as big as a factor of three. ${ }^{15}$ This home bias is surprising but is a fact of life. Something needs to explain it, and there are not very many candidates other than exchange rate variability. Thus, the Rose findings remain a challenge to the traditional views of international economists, who believed that trade

14. Baldwin cites approvingly an assertion of Berger and Nitsch (2005) that it is implausible, even crazy, to think that the trade effect of the euro could be as large as the trade effect of the European Union. But this finding is common econometrically. If critics were to apply the same tough standards to both customs unions and currency unions, they would likely find the estimated magnitude at least as large in the latter case as in the former. As traditionally specified, this is a tripling.

15. McCallum (1995), Helliwell (1998), Wei (1996), and Nitsch (2000, 1991). 
barriers were far more important than either currency differences or other remaining barrier frictions.

\subsubsection{Country Size}

The fifth critique is the claim that the result from pre-1999 currency unions are relevant only for small countries, which are highly trade dependent, but are less relevant for larger countries, such as those in Europe. A partial response has been possible all along: there has been no evidence of the monetary union effect varying with size within the available sample. But if one suspects a threshold effect, above which the monetary union effect diminishes, and if one posits that euro members are the first to be big enough to lie above that threshold, then this could explain the gap. The question of whether the largest economies are truly different can only be answered with data from those countries. Fortunately, the euro experiment is now ten years old, and so we should hope to be able to answer the question. But to do so, we will have to expand our view beyond the sort of data set used by Micco, Stein, and Ordoñez (2003), which was limited to European countries, or at most, to the set of industrialized countries, and we will have to nest it within the larger sort of data set used by Rose, which captures trade among all countries.

\subsection{Econometric Investigation of the Euro-Rose Gap in Estimated Effects}

The tasks addressed in the remainder of this chapter are first, to confirm that the effects of the euro to date, even if statistically significant, are still relatively small, even with the addition of the several extra years of data that are now available, and second - and more importantly - to try to explain the gap. Three candidate explanations for the gap are the most obvious possibilities:

- Time is needed for gradual adjustment.

- Currency union effects for large countries are fundamentally different from those for small countries.

- Earlier estimates from pre-1999 samples of currency unions were biased upward by endogeneity.

\subsubsection{Reproduction of Findings for Early Euro Years: Jumping the Gun}

We begin by reproducing the results in Micco, Stein, and Ordoñez (2003), who estimated the effect of the euro on trade patterns for a relatively narrow sample: Europe (or alternatively, for all industrialized countries) during the period from 1992 to 2002. Table 5.1 does successfully replicate the results: pairs of euro countries enjoy greater bilateral trade, with a coefficient that first appears suddenly significant in 1998 and then gradually rises in level and significance through 2002 (also see figure 5.1). 
Table 5.1

Recreation of estimated effects on bilateral trade patterns in the first three years of the euro

\begin{tabular}{|c|c|c|c|c|}
\hline & \multicolumn{2}{|c|}{ Developed sample } & \multicolumn{2}{|c|}{ EU sample } \\
\hline & Coefficient & $\begin{array}{l}\text { Standard } \\
\text { error }\end{array}$ & Coefficient & $\begin{array}{c}\text { Standard } \\
\text { error }\end{array}$ \\
\hline EMU2-1993 & -0.0176 & 0.0331 & -0.0068 & 0.0295 \\
\hline EMU2-1994 & 0.0377 & 0.0337 & 0.0246 & 0.0296 \\
\hline EMU2-1995 & 0.0512 & 0.0340 & 0.0162 & 0.0297 \\
\hline EMU2-1996 & 0.0359 & 0.0345 & 0.0000 & 0.0296 \\
\hline EMU2-1997 & 0.0443 & 0.0350 & 0.0175 & 0.0296 \\
\hline EMU2-1998 & 0.0981 & $0.0358 * * *$ & 0.0637 & $0.0296^{* *}$ \\
\hline EMU2-1999 & 0.1166 & $0.0360 * * *$ & 0.0731 & $0.0297^{* *}$ \\
\hline EMU2-2000 & 0.1036 & $0.0367 * * *$ & 0.0762 & $0.0300^{* * *}$ \\
\hline EMU2-2001 & 0.1351 & $0.0369 * * *$ & 0.1662 & $0.0298 * * *$ \\
\hline EMU2-2002 & 0.1544 & $0.0368^{* * *}$ & 0.1644 & $0.0297 * * *$ \\
\hline Log of product of real GDPs & 1.1382 & $0.0464 * * *$ & 1.0620 & $0.0520^{* * *}$ \\
\hline Free trade agreement & -0.0097 & 0.0188 & 0.0453 & 0.0300 \\
\hline EU & 0.0095 & 0.0239 & -0.0470 & 0.0467 \\
\hline EU trend & -0.0008 & 0.0014 & -0.0013 & 0.0035 \\
\hline Real exchange rate of country 1 & -0.1737 & $0.0453^{* * *}$ & -0.1872 & $0.0627^{* * *}$ \\
\hline Real exchange rate of country 2 & -0.2643 & $0.0518^{* * *}$ & 0.3738 & $0.0885^{* * *}$ \\
\hline Observations & 2,541 & & 1,001 & \\
\hline Within $R^{2}$ & 0.462 & & 0.671 & \\
\hline Between $R^{2}$ & 0.686 & & 0.784 & \\
\hline Overall $R^{2}$ & 0.684 & & 0.783 & \\
\hline
\end{tabular}

Notes: Recreation of Micco, Stein, and Ordoñez (2003) on their original data sample and methodology (EMU impact on trade: data from 1992 to 2002). Includes year and country-pair fixed effects.

***Significant at the 1 percent level.

**Significant at the 5 percent level.

Why does the effect show up in 1998, the year before EMU? It is likely that currency unions, much as FTAs, can start to have substantial effects on trade patterns even before they have formally gone into effect. This pattern is familiar in the data. ${ }^{16}$ The most obvious interpretation is that once the negotiations, which typically have been going on for many years, are far enough along that the union appears almost certain to take place, businessmen move quickly to try to establish a position in what is expected to be a large new market opportunity, perhaps to get a "first mover advantage." This argument works best theoretically in the case of markets destined for imperfect competition. But even in perfectly competitive markets, firms might want to get started early if there are transition costs associated with rapid investment in a new market.

16. For example, Frankel (1997). 


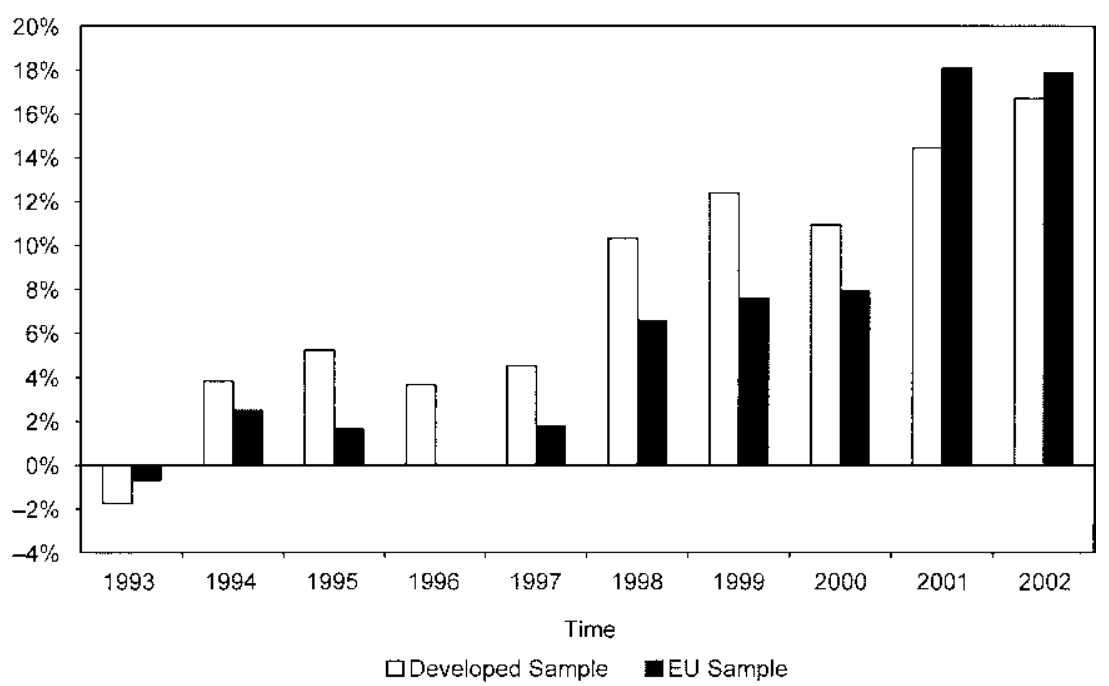

Fig. 5.1 Results from a study of the trade effects in the early years; Micco, Stein, and Ordoñez (2003): EMU impact on trade

Baldwin (2006) regards as suspicious the striking fact that the estimated effect in euroland appears suddenly in 1998, even though EMU did not take effect until January 1999. Even allowing the principle that business perceptions of imminent monetary union can set the date rather than waiting for 1999, he claims that "right up to . . . March 1998, skeptics doubted that the monetary union would ever become a reality" (52). But statistics from financial markets tend to identify June 1997 as the breakpoint in perceptions. ${ }^{17}$ So, it is plausible that businesses had started reacting in a measurable way by 1998 .

Next, we updated the results, because another four years of data have become available. We find that the effect of the euro on bilateral trade remains highly significant statistically during the years from 2003 to 2006 but that the point estimate is no longer rising. Rather, it appears to have leveled off at approximately 0.1 , still very far below the Rose estimates of doubling or tripling. In the EU-only sample, the coefficient on intraeuroland trade rises to a highly significant estimated level of 0.13 to 0.16 in 2001 to 2002 but does not rise any further in 2003 to 2006. In the sample that includes all developed countries, the euro effect becomes significant in 2003 at 0.11 but does not continue its upward trend during 2004 to 2006 (see table 5.2).

17. On June 15, 1997, implied probabilities of joining Germany in EMU in 1999 were 100 percent for Belgium and France and over 70 percent for Finland, Spain, and Portugal (calculations from JP Morgan based on spreads in the interest rate swap market). A similar statistic from Goldman Sachs on the probability of EMU taking place on January 1, 1999, shot up above 75 percent after the Stability and Growth Pact was agreed in June 1997. 
Table 5.2 Update of table 5.1: Creation of estimated effects on bilateral trade patterns in the first eight years of the euro

\begin{tabular}{|c|c|c|c|c|}
\hline & \multicolumn{2}{|c|}{ Developed sample } & \multicolumn{2}{|c|}{ EU sample } \\
\hline & Coefficient & $\begin{array}{l}\text { Standard } \\
\text { Error }\end{array}$ & Coefficient & $\begin{array}{c}\text { Standard } \\
\text { Error }\end{array}$ \\
\hline EMU2-1993 & -0.0489 & 0.0457 & -0.0137 & 0.0352 \\
\hline EMU2-1994 & -0.0297 & 0.0463 & -0.0060 & 0.0352 \\
\hline EMU2-1995 & -0.0258 & 0.0458 & -0.0113 & 0.0352 \\
\hline EMU2-1996 & -0.0300 & 0.0461 & -0.0132 & 0.0352 \\
\hline EMU2-1997 & -0.0138 & 0.0464 & 0.0007 & 0.0352 \\
\hline EMU2-1998 & 0.0315 & 0.0463 & 0.0453 & 0.0352 \\
\hline EMU2-1999 & 0.0205 & 0.0468 & 0.0707 & $0.0358 * *$ \\
\hline EMU2-2000 & -0.0064 & 0.0469 & 0.0719 & $0.0358 * *$ \\
\hline EMU2-2001 & 0.0650 & 0.0469 & 0.1621 & $0.0355^{* * *}$ \\
\hline EMU2-2002 & 0.0698 & 0.0469 & 0.1306 & $0.0354^{* * *}$ \\
\hline EMU2-2003 & 0.1102 & $0.0469 * *$ & 0.1334 & $0.0354^{* * *}$ \\
\hline EMU2-2004 & 0.1160 & $0.0467 * * *$ & 0.1507 & $0.0354 * * *$ \\
\hline EMU2-2005 & 0.0940 & $0.0469^{* *}$ & 0.1385 & $0.0354 * * *$ \\
\hline EMU2-2006 & 0.0806 & $0.0481^{*}$ & 0.1450 & $0.0354 * * *$ \\
\hline Log of product of real GDPs & 0.6623 & $0.0378 * * *$ & 0.4090 & $0.0341 * * *$ \\
\hline Free trade agreement & 0.0066 & 0.0163 & -0.0669 & $0.0232 * * *$ \\
\hline EU & (dropped) & & (dropped) & \\
\hline EU trend & 0.0000 & 0.0017 & -0.0019 & 0.0015 \\
\hline Real exchange rate of country 1 & -0.0184 & $0.0032 * * *$ & 0.0006 & 0.0029 \\
\hline Real exchange rate of country 2 & -0.0004 & 0.0027 & 0.0074 & $0.0024 * * *$ \\
\hline Observations & 2,850 & & 1,170 & \\
\hline Within $R^{2}$ & 0.998 & & 0.999 & \\
\hline Between $R^{2}$ & 0.650 & & 0.804 & \\
\hline Overall $R^{2}$ & 0.920 & & 0.929 & \\
\hline
\end{tabular}

Notes: EMU impact on trade: data from 1992 to 2002. Update: euro effect continues strong, 2001 to 2006. Includes year and country-pair fixed effects.

***Significant at the 1 percent level.

**Significant at the 5 percent level.

*Significant at the 10 percent level.

\subsubsection{Effect of Size}

Table 5.3 investigates whether the effects of monetary union diminish with the size of the countries involved. It adds an interactive size term, computed as the product of the sizes of the respective countries and the dummy variable for currency union membership. The intent is to explore the hypothesis that currency union effects on trade are bigger for small countries than for large countries and that this might explain the relatively smaller effect in Europe. It is true that larger countries experience smaller boosts to intraunion trade: the interactive term is statistically significant. But the effect is still not significant within non-EMU monetary unions. Rather, it appears within 
Table 5.3

Currency union effect diminishes with size only within EMU but not among other countries

\begin{tabular}{|c|c|c|}
\hline Log of bilateral trade & OLS Gravity estimates & Fixed effects (Country-pair) \\
\hline Currency union $(\mathrm{CU})$ & $\begin{array}{c}1.1778 \\
(2.5491)\end{array}$ & $\begin{array}{l}-2.8473 * * * \\
(0.5906)\end{array}$ \\
\hline EMU & $\begin{array}{l}15.3995^{* *} \\
(7.5823)\end{array}$ & (dropped) \\
\hline $\mathrm{CU} * \log$ product of real GDPs & $\begin{array}{c}-0.0172 \\
(0.0550)\end{array}$ & $\begin{array}{l}0.0655^{* * *} \\
(0.0132)\end{array}$ \\
\hline $\mathrm{EMU}^{*} \log$ product of real GDPs & $\begin{array}{c}-0.2695^{*} \\
(0.1539)\end{array}$ & $\begin{array}{c}0.0186 \\
(0.0310)\end{array}$ \\
\hline Log distance & $\begin{array}{l}-0.8772 * * * \\
(0.0456)\end{array}$ & $\begin{array}{l}0.3096^{* * * *} \\
(0.0106)\end{array}$ \\
\hline Log product of real GDPs & $\begin{array}{l}0.7458^{* * * *} \\
(0.0123)\end{array}$ & $\begin{array}{l}0.1045^{* * * *} \\
(0.0169)\end{array}$ \\
\hline Log product of real GDP/capita & $\begin{array}{c}0.0242 \\
(0.0151)\end{array}$ & $\begin{array}{l}1.0935^{* * * *} \\
(0.0160)\end{array}$ \\
\hline Common language & $\begin{array}{l}0.2589^{* * * *} \\
(0.0746)\end{array}$ & $\begin{array}{l}-0.0407^{* *} \\
(0.0179)\end{array}$ \\
\hline Common land border & $\begin{array}{l}0.0746^{* * *} \\
(0.1854)\end{array}$ & $\begin{array}{l}-0.4764^{* * * *} \\
(0.0504)\end{array}$ \\
\hline Regional FTA membership & $\begin{array}{l}0.4199 * * * \\
(0.1669)\end{array}$ & $\begin{array}{c}0.0079 \\
(0.0384)\end{array}$ \\
\hline Number landlocked & $\begin{array}{l}-0.4382^{* * * *} \\
(0.0642)\end{array}$ & $\begin{array}{l}0.2127 * * * \\
(0.0152)\end{array}$ \\
\hline Area & $\begin{array}{l}-0.1048^{* * *} \\
(0.0114)\end{array}$ & $\begin{array}{l}-0.1123^{* * *} \\
(0.0024)\end{array}$ \\
\hline Common colonizer & $\begin{array}{l}0.4360^{* * * *} \\
(0.1306)\end{array}$ & $\begin{array}{l}0.0715^{* * * *} \\
(0.0285)\end{array}$ \\
\hline Current colony/colonizer & $\begin{array}{l}1.7076 * * * \\
(0.4883)\end{array}$ & $\begin{array}{l}0.4120 * * * \\
(0.0976)\end{array}$ \\
\hline Ever colony/colonizer & $\begin{array}{c}0.0731 \\
(0.1189)\end{array}$ & $\begin{array}{l}-1.1098 * * * \\
(0.0407)\end{array}$ \\
\hline Common country & $\begin{array}{c}2.4202 \\
(3.2544)\end{array}$ & (dropped) \\
\hline Intercept & $\begin{array}{l}-23.2333^{* * * *} \\
(0.5598)\end{array}$ & $\begin{array}{l}-6.7655^{* * *} \\
(0.6212)\end{array}$ \\
\hline $\begin{array}{l}\text { Observations } \\
\text { OLS } R^{2}\end{array}$ & $\begin{array}{l}297,322 \\
0.4955\end{array}$ & 297,322 \\
\hline Within $R^{2}$ & & 0.6868 \\
\hline Between $R^{2}$ & & 0.0911 \\
\hline Overall $R^{2}$ & & 0.2861 \\
\hline
\end{tabular}

Notes: Includes currency union and EMU dummies, interaction variable between currency union and country size, elapsed time variables, and year fixed effects. Standard errors recorded in parentheses. (For OLS regression, standard errors are robust to country-pair clustering.) Based on annual data for 217 countries from 1948 to 2006.

***Significant at the 1 percent level.

**Significant at the 5 percent level.

*Significant at the 10 percent level. 
EMU. (The effect of EMU on bilateral trade remains, even after controlling for size.) We need to imbed the sample of European or industrialized countries within a more comprehensive set of countries before we can pass judgment on the claim that size explains the difference in effects.

\subsubsection{Imbedding Euro Estimates in a Larger Sample of Countries and Time}

To try to nail down the gap between the euro estimates of a 10 to 15 percent effect and the Rose-style estimates of a tripling, it is necessary to imbed the euro data set inside an updated version of the larger cross-country data sets employed by Rose and others. Micco, Stein, and Ordoñez (2003), like some of their competitors, looked only at a set of European countries, or at most, a set of rich countries. When we imbed the data set from tables 5.1 and 5.2 inside the larger data set, we can explicitly control for size and a Europe dummy to try to isolate where the big gap arises.

What follows are step-by-step results leading from Micco, Stein, and Ordoñez (2003) up to the higher results (from the 15 percent effect to the tripling effect; see table 5.4). We pursue the step-by-step analysis in two different dimensions: first, we use the two samples that MSO use (developed countries and EU sample) as well as our full sample at every step to show what difference the sample makes. Second, we start with a sample for 1992 to 2006. (This is the start date of MSO, but their data set stopped at 2001.) We then expand this to our full data set from 1948 to 2006 to see what difference the addition of the earlier observations makes. We also show both fixed effects (with country-pair fixed effects and year effects) and ordinary least squares (OLS; with year fixed effects).

Table 5.5 shows the estimation results, followed by the corresponding figure 5.2, for the first step: the 1992 to 2006 sample with only one dummy for EMU (no EMU-time interactions). We see that the euro effect exceeds 10 percent only when estimated within the EU sample. The estimates for the effect of the EMU on bilateral trade using the full sample or developed country sample are lower-around 6 percent - and they fail to be significant for the full sample. Using OLS instead of fixed effect estimators decreases the effect significantly for the full and developed country samples but increases it to above 30 percent for the EU sample.

Table 5.6 and the corresponding figures that follow (figures 5.3 and 5.4) remain in the 1992 to 2006 sample time frame but add EMU-year interaction terms to the specification so that we can follow the evolution of the euro's effect over time. We can recreate (as we did previously) the MSO results for the developed and EU samples that they used: estimates are significant during the euro period..$^{18}$ The effect of the euro on trade rises steadily from 1998, reaching the statistically significant level of 0.15 to 0.17 in 2001 to 2002 .

18. The reader should not be confused by the EMU-year interactive effects in the OLS column, which in most years can be taken to be essentially 0 . The coefficient to focus on is the 
We have added four years to the sample relative to the initial round of studies. The euro effect remains in the same range and remains statistically significant. But it does not continue to increase over the period from 2002 to 2006. For the author, the most surprising finding of this study was the absence of any evidence that the effects of the euro on bilateral trade have continued to rise during the second half of the eight-year history of the euro. This seems counter to historical experience in other countries with lags in bilateral trade effects from both currency union entries/exits and other factors.

The results become less clear when we apply the specification to the full sample of countries. (The effect appears slightly negative for the years from 1993 to 1996, jumps up in 1997, and becomes negative again in 2005 to 2006, but none of these estimates is significant in the full sample. $)^{19}$ This might seem to justify the MOS strategy of having confined their estimation to samples of EU and developed countries under the logic that developing countries are too different to be useful. The most important point to note for our purposes, however, is that the coefficient on non-EMU currency unions remains a significant 0.75 (under OLS ${ }^{20}$ ). The exponential of 0.75 is 2.1 , so this is a doubling of bilateral trade. The existence of the gap between small estimates for the euro (not even significant in this sample) and big estimates for other monetary unions is still very much in evidence. But we need a longer time sample if we want to obtain more reliable estimates and sharpen our standard errors.

Table 5.7 and the subsequent figure 5.5 show step 2: we now expand the data set to 1948 to 2006, which covers almost sixty years of data. The graph reveals that a crucial difference between MSO and broader estimates was the sample size. While estimates of the euro's effect on trade continue to linger around 10 to 25 percent for the developed and EU samples that MSO used, they have climbed dramatically to 0.9 to 1.0 for the full sample, which exponentially is 2.5 to 2.7 -almost tripling. All these estimates are highly significant now that we have more data with which to work. We have uncovered the possibility that the large gap is an artifact of the largely nonoverlapping historical periods analyzed in the Rose and MOS studies (pre- and post-1999, respectively). Interestingly, the estimated trade effects of the euro are now even larger and more significant than the trade effects of non-EMU currency unions rather than the other way around. Moreover, for those

dummy "both countries in EMU," which is a highly significant 0.354 . One needs to add this coefficient to the year estimates. Look at the bar charts in the figures to see this. In 1996, the 0.354 coefficient is almost knocked out by the significant negative year effect. Thereafter, it dominates (i.e., 0.354).

19. When we use OLS, estimates are positive only for the developed and EU samples, but they seem strange - for the EU sample, they start rather high in 1993, decrease slightly until 1996, and then take off again until a high in 2004. Only in 1994 to 1997 are they significant.

20. It loses some luster under fixed effects, but this is perhaps to be expected, as there are only fifteen years of observations, and much of the variation in the data is eaten up by fixed effects and interactive year dummies. 
Dependent variable Log of bilateral trade

A. 1948 to 2006: Fixed effects estimator with country-pair fixed effects

Currency union

Currency union $\times \log$ of product of real GDPs

Free trade agreement

0.113

$(0.069)$

Log of product of real GDPs

$-1.612^{* * *}$ (0.018)

Log of product of real GDPs per capita

Currently in colonial relationship

Real exchange rate of country 1

1.032

$(0.815)$

$0.068^{* * *}$

$(0.005)$

Real exchange rate of country 2

$0.134 * * *$

$(0.012)$

Constant

Observations

168,174

Number of identifications

10,739

$R^{2}$

0.09

B. 1948 to 2006: Fixed effects estimator with country-pair and year fixed effects.

Currency union

Currency union $\times \log$ of product of real GDPs

Free trade agreement

Log of product of real GDPs

$(0.068)$

Log of product of real GDPs per capita

$0.127^{* * *}$

(0.044)

$1.484 * * *$

Currently in colonial relationship

Real exchange rate of country 1

0.811

$(0.794)$

$-0.029 * * *$

Real exchange rate of country 2

$(0.005)$

$0.073^{* * *}$

$(0.012)$

Constant

Observations

168,174

Number of identifications

10,739

$R^{2}$

0.14

Note: Standard errors in parentheses.

***Significant at the 1 percent level.

**Significant at the 5 percent level.

*Significant at the 10 percent level. 


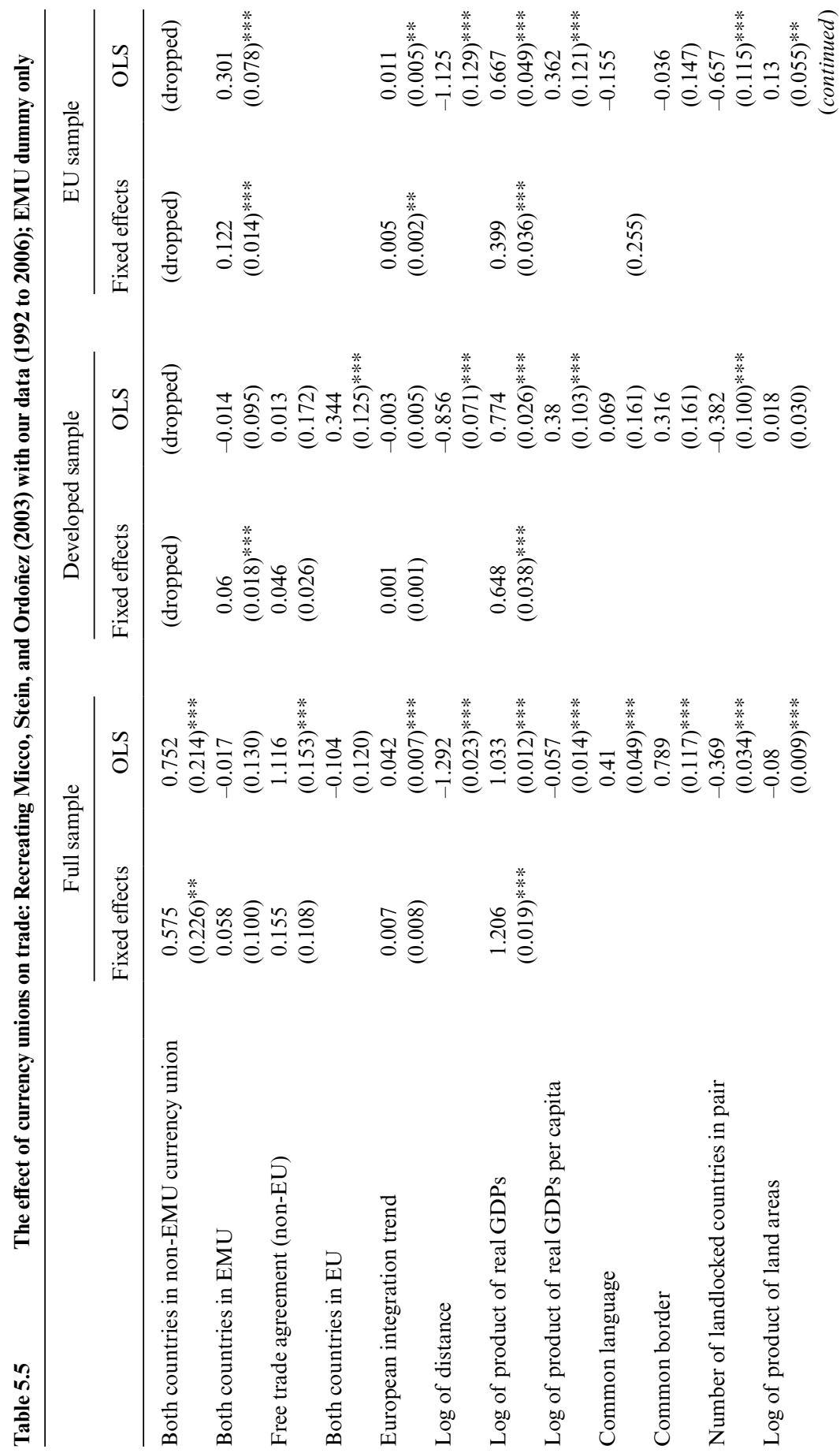




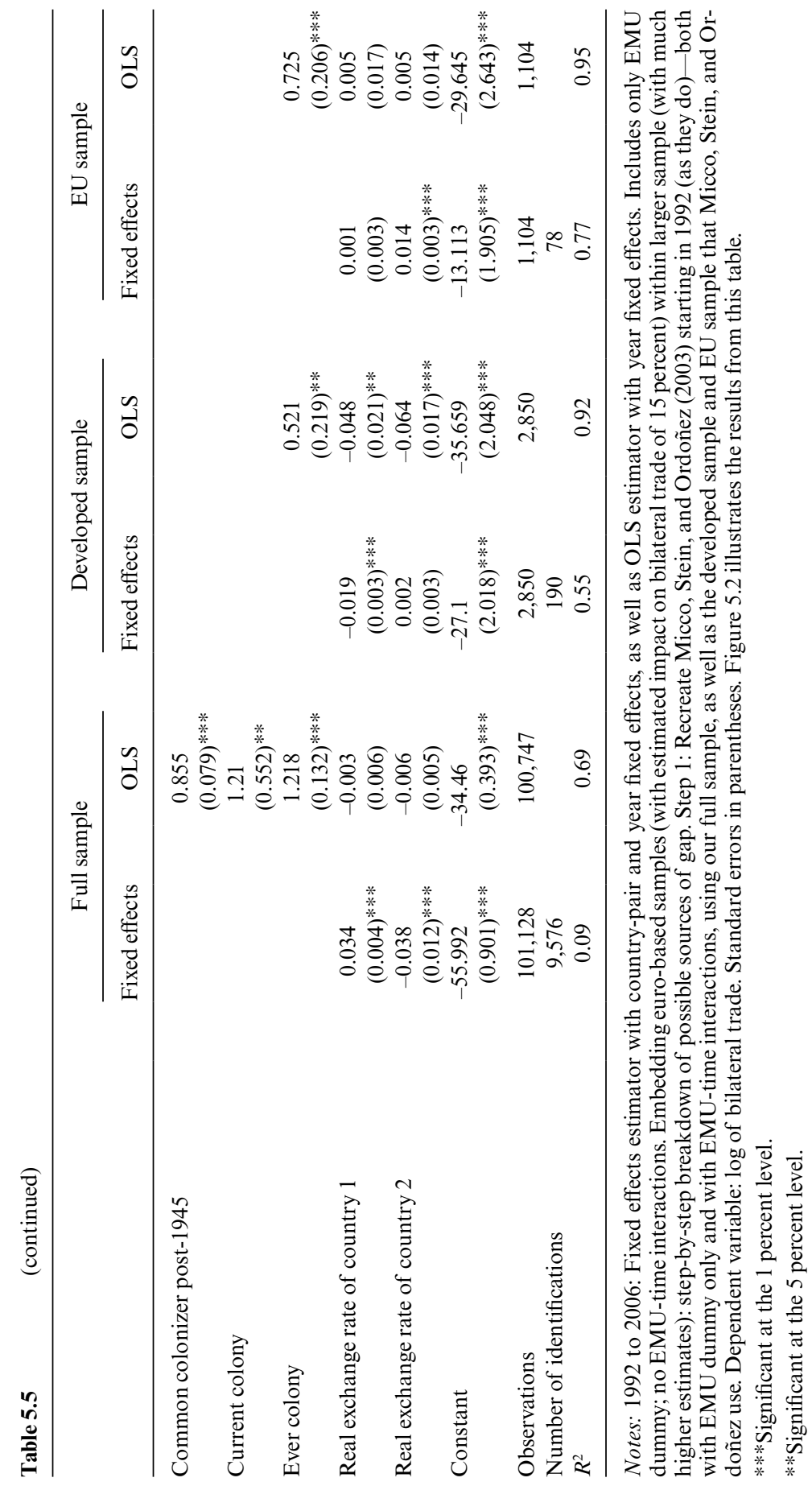




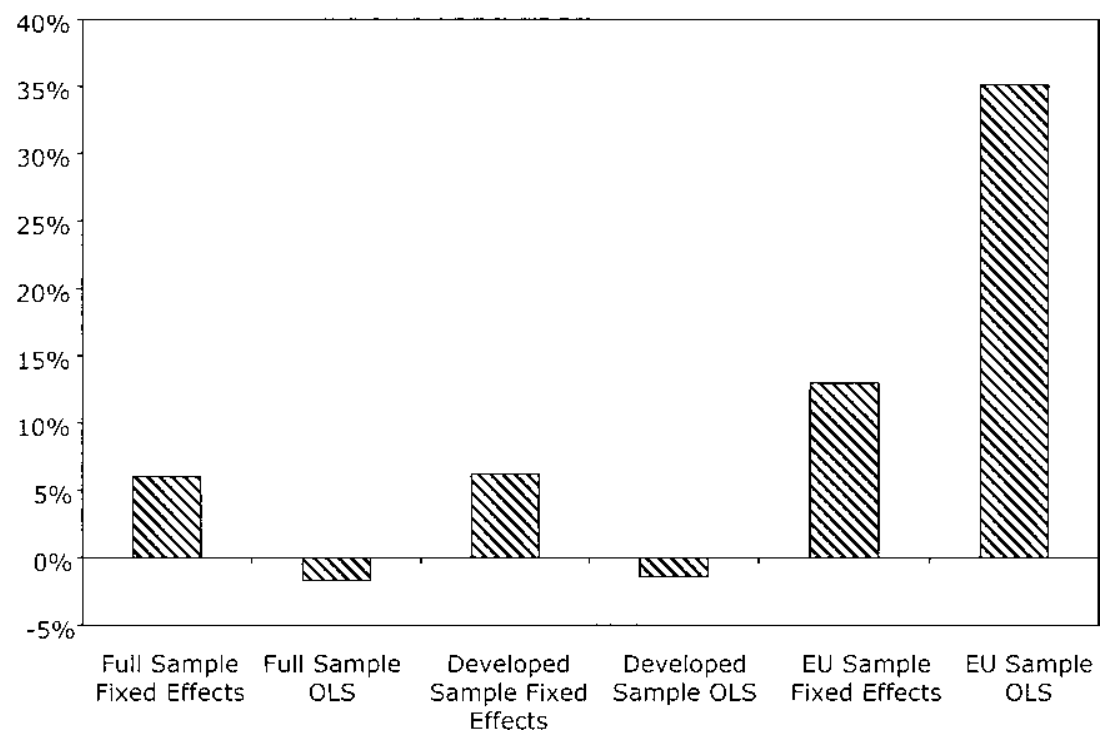

Fig. 5.2 The effect of EMU on trade: Different estimators and samples (1992 to 2006)

concerned with the Van Wincoop view that the gravity specification used here overstates what would be the percentage effect of joining (or leaving) a monetary union, it is worth noting that the estimated coefficient of EMU is larger than that on the European Union or other FTAs, and this is a comparison that stands up with fixed country effects.

There appears to be much useful information from including all sixty years of available data in addition to including developing countries in the entire sample rather than restricting ourselves to post-1992 observations of European or rich countries. Estimates such as those for the coefficients on common border or common language shift substantially when the more complete data set is brought to bear. Only by using the entire sample can we uncover large short-term effects - over 100 percent when using fixed effects estimation. Second, the trade effects in the year before a monetary union formally goes into operation are even larger and apply equally to EMU as to other monetary unions.

Table 5.8 continues the analysis of the full sixty-year data set but now adds interaction effects between EMU and years before and after entry; it does the same for non-EMU monetary unions. We aggregate over each five-year interval in order to cut down on the loss of degrees of freedom, and because it is implausible to think that there are sharp changes between, say, effects in years 19 and 20. The corresponding figures 5.6 and 5.7 show the interaction effects both for non-EMU currency unions and for EMU: the bar with 


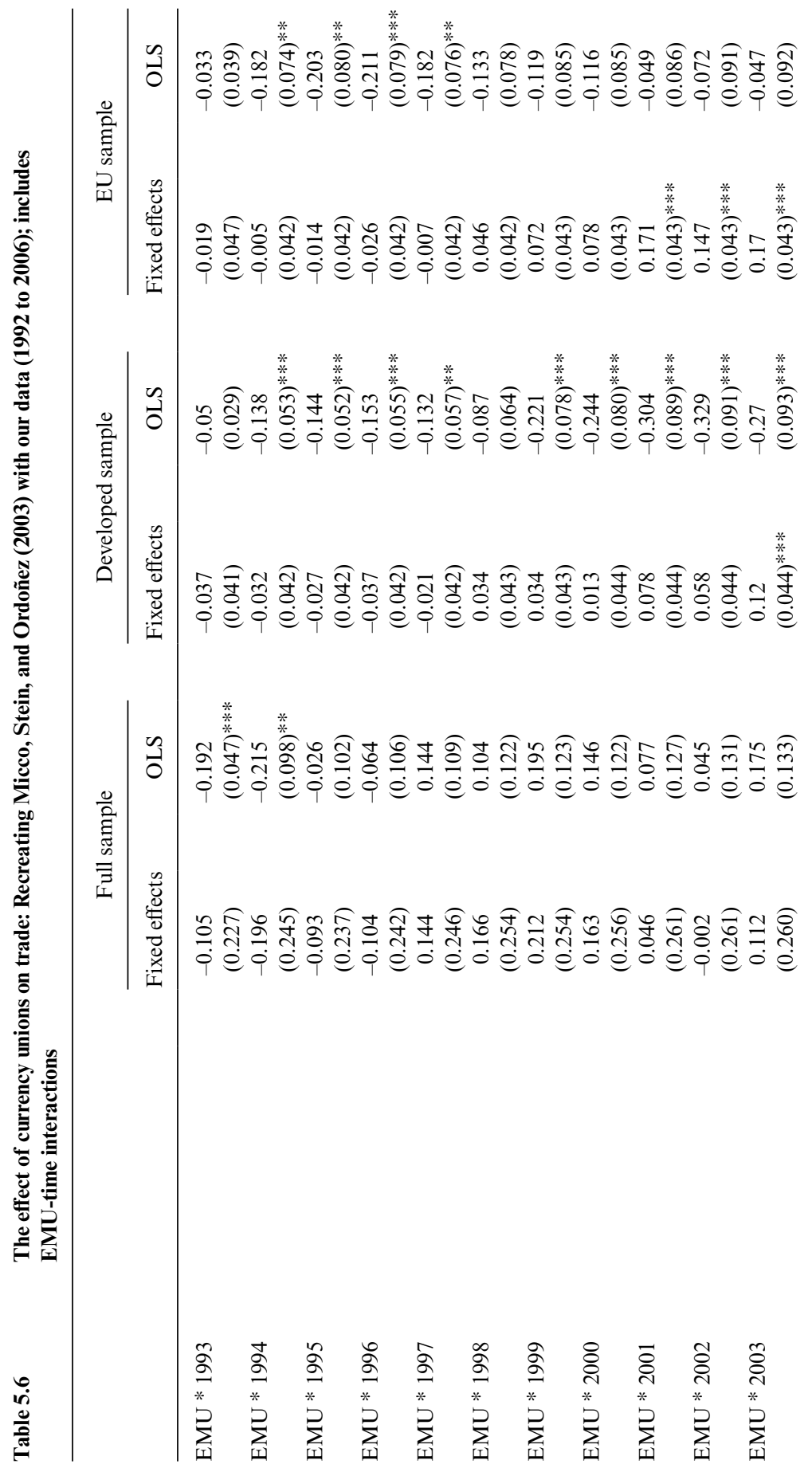




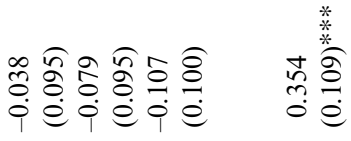

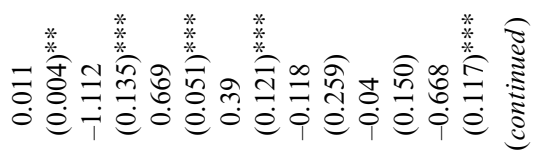

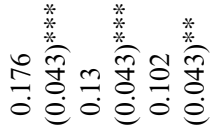

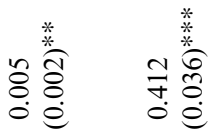

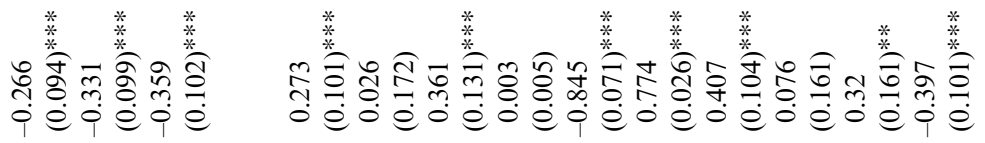

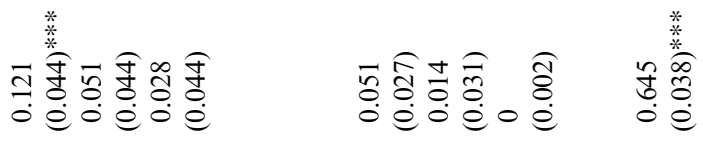

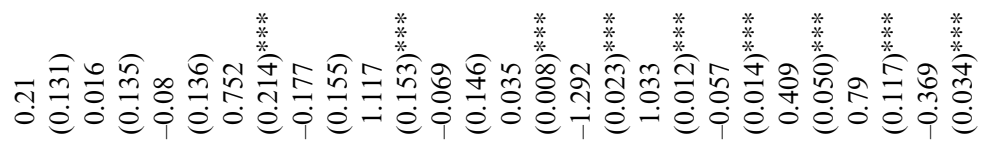

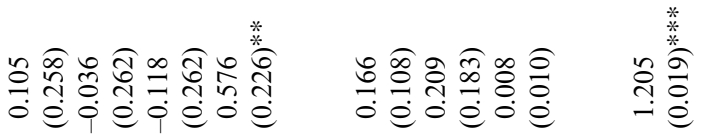

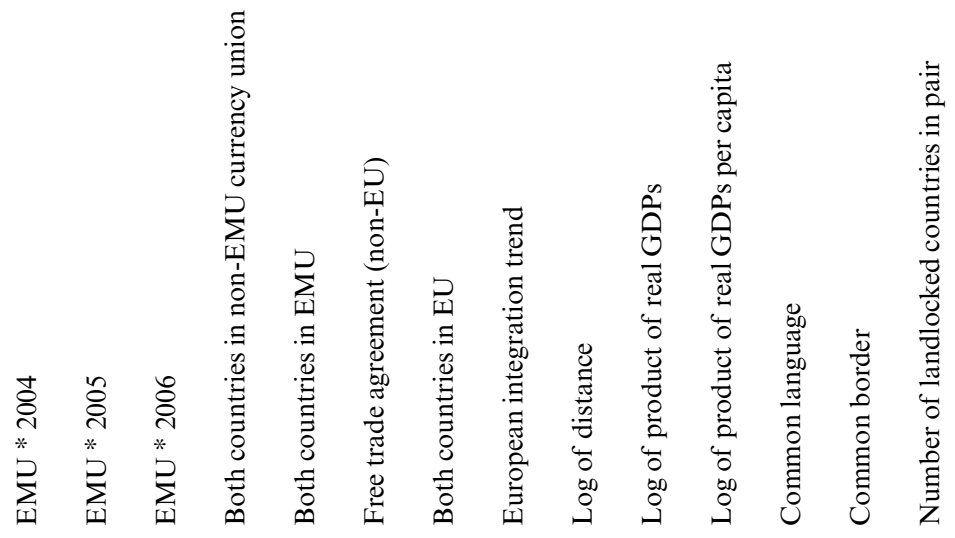




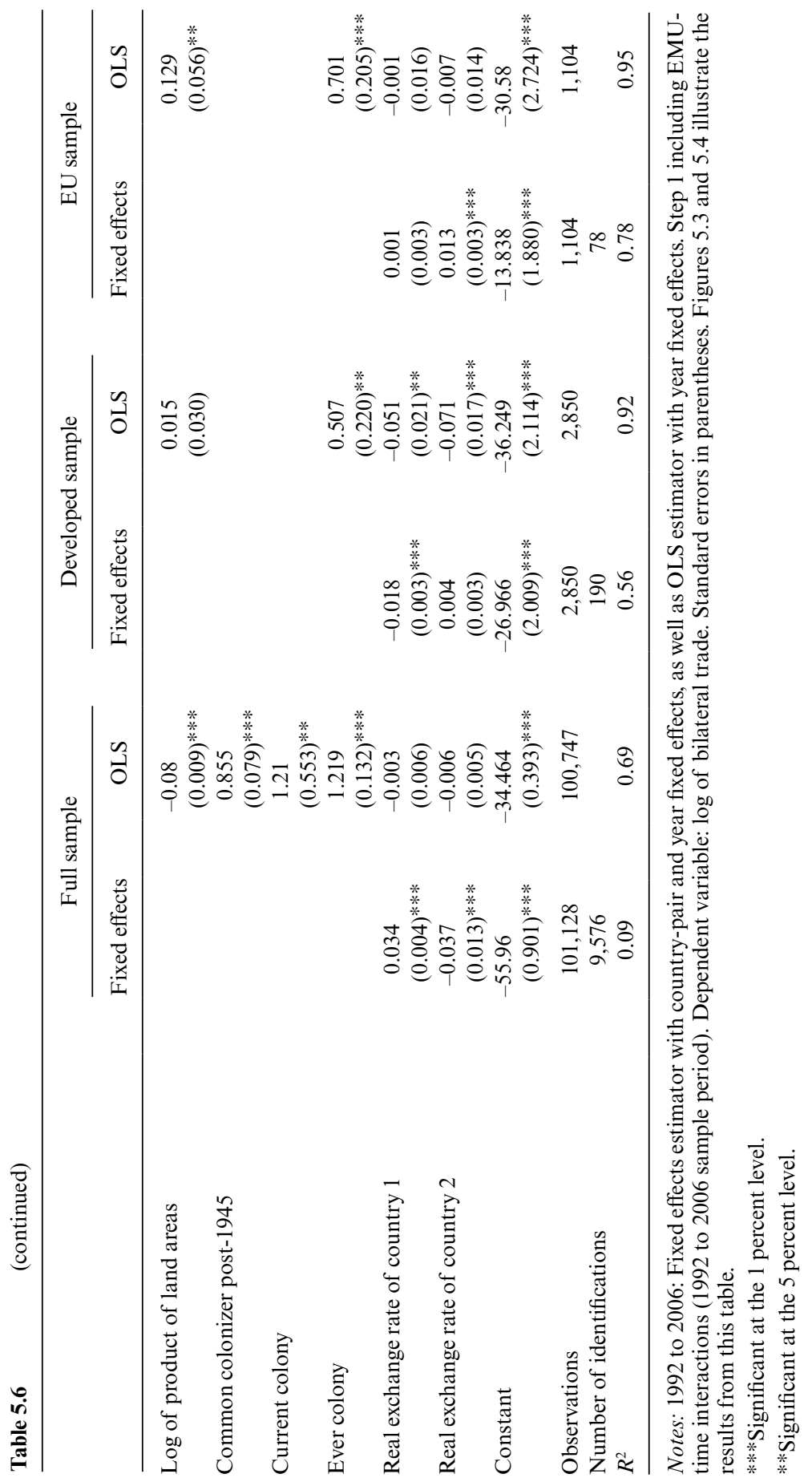




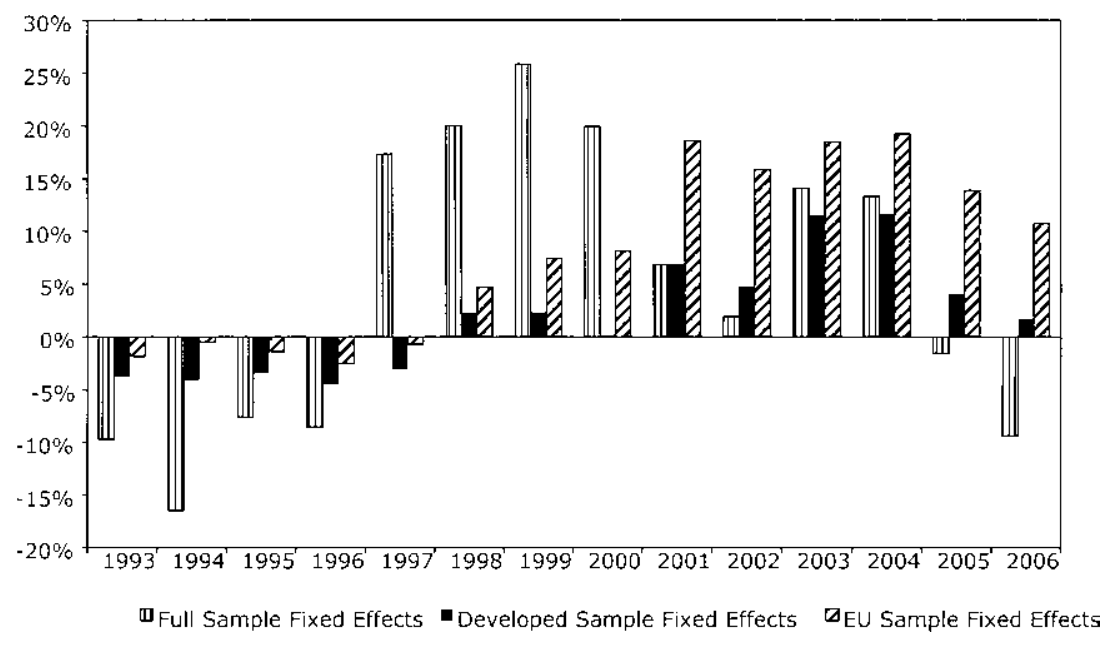

Fig. 5.3 The effect of EMU on bilateral trade; Recreating Micco, Stein, and Ordoñez (2003) with our data: Fixed effects estimators

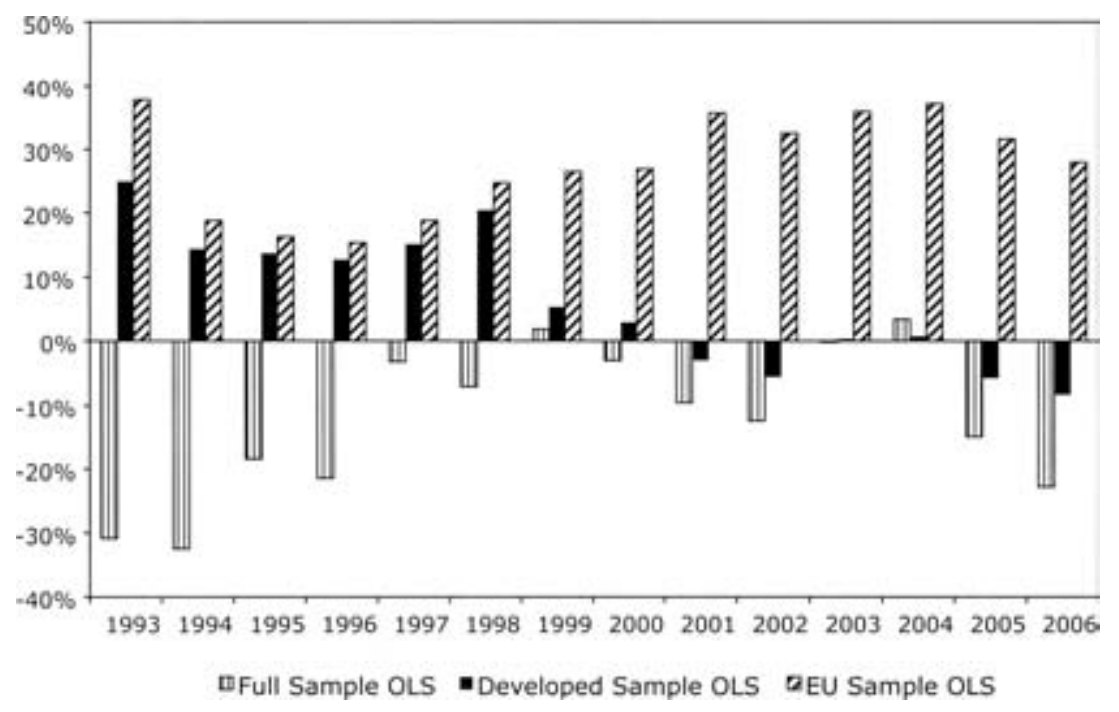

Fig. 5.4 The effect of EMU on bilateral trade; Recreating Micco, Stein, and Ordoñez (2003) with our data: OLS estimators 


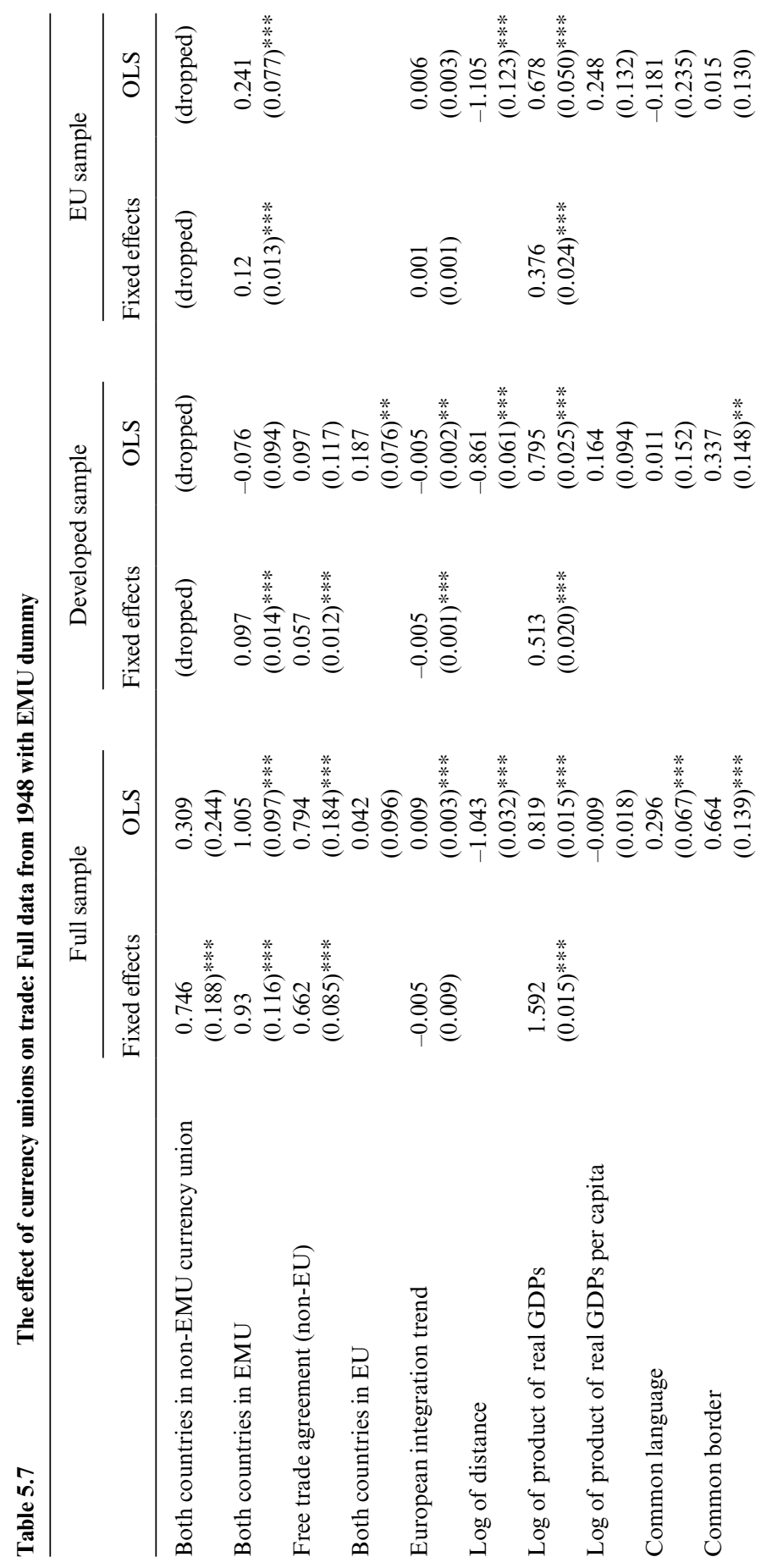




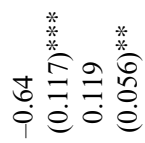

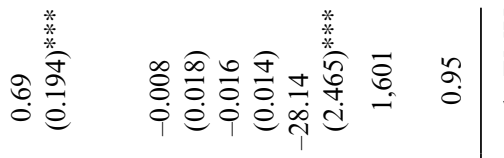

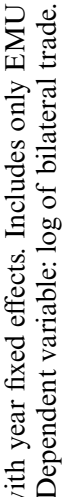

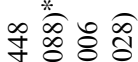

商

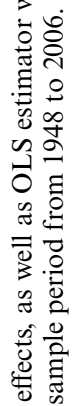

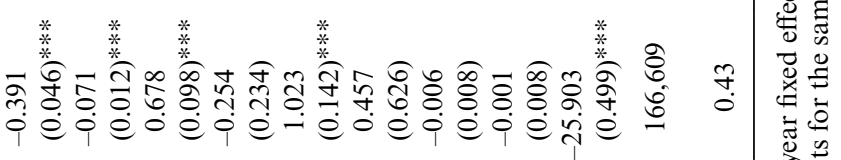

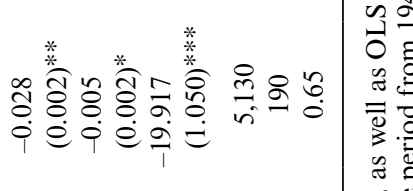

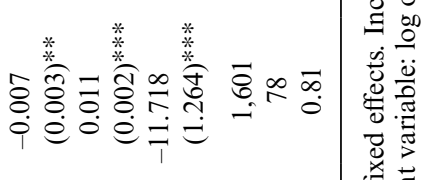
iei

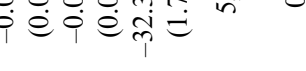

突 


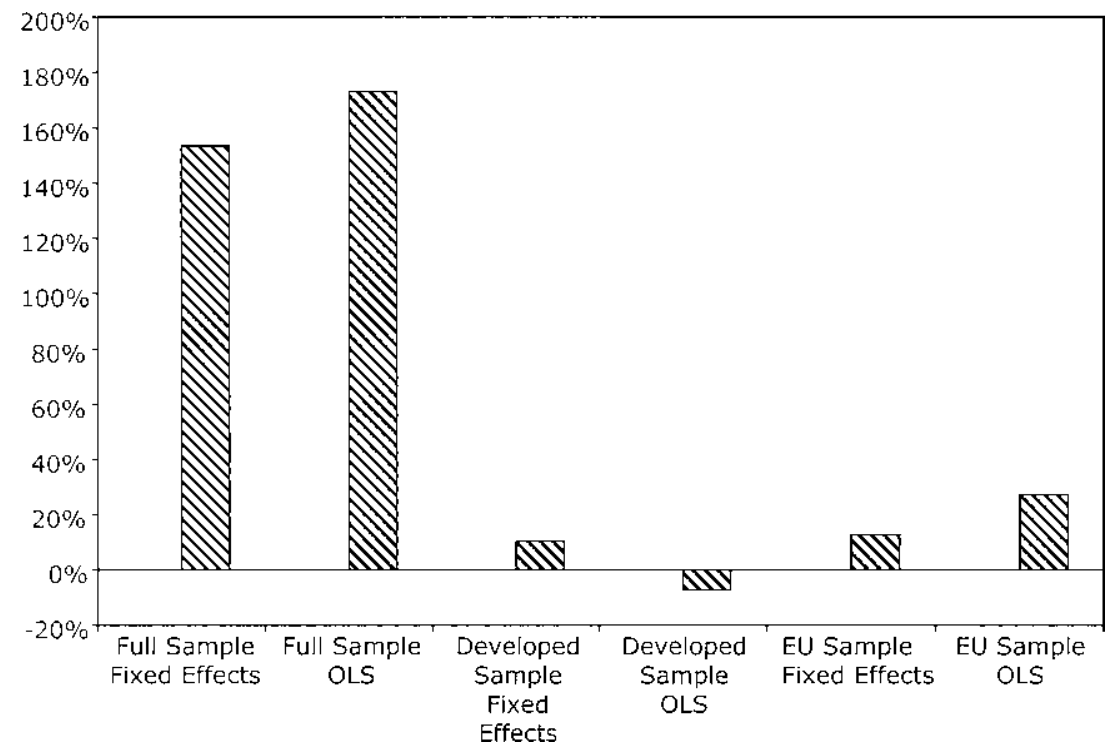

Fig. 5.5 The effect of EMU on trade: Different estimators and samples (1948 to 2006)

horizontal stripes represents the full-sample estimates for non-EMU currency union interactions with " 1 yr. prior to CU entry," " $1-5$ yrs. post," "6-10 yrs. post," "11-15 yrs. post," "16-20 yrs. post," "21-25 yrs. post," and "26-30 yrs. post." The other three bars represent the estimates for the interaction terms of EMU with different years prior and post-EMU entry based on the three different sample sizes (full: vertical stripes; developed: solid black; EU: diagonal stripes). As there are no non-EMU currency unions in the developed sample, we only have the full-sample estimate for the nonEMU currency union interactions with time.

The central puzzle addressed by this chapter, the huge discrepancy between the euro effects to date and other monetary unions, seems to be sharply diminished here. It is true that in the one year prior to monetary union, the apparent effect is huge for noneuro monetary unions and that also in the first five years, it is several times larger. Perhaps reverse causality is a particular problem in these cases. But in years 6 to 10, the difference between EMU and noneuro currency unions is much smaller.

That the trade effects fail to rise in years 6 to 10 relative to years 1 to 5 turns out to apply to other currency unions as much as to EMU—in fact, more so. To help decide whether this is telling us that the long-run effect is reached within five years, we need to look at the out-years for the non-EMU cases (because there are no EMU observations out further than ten years). The long-run effects depend entirely on whether one looks at fixed effects or 


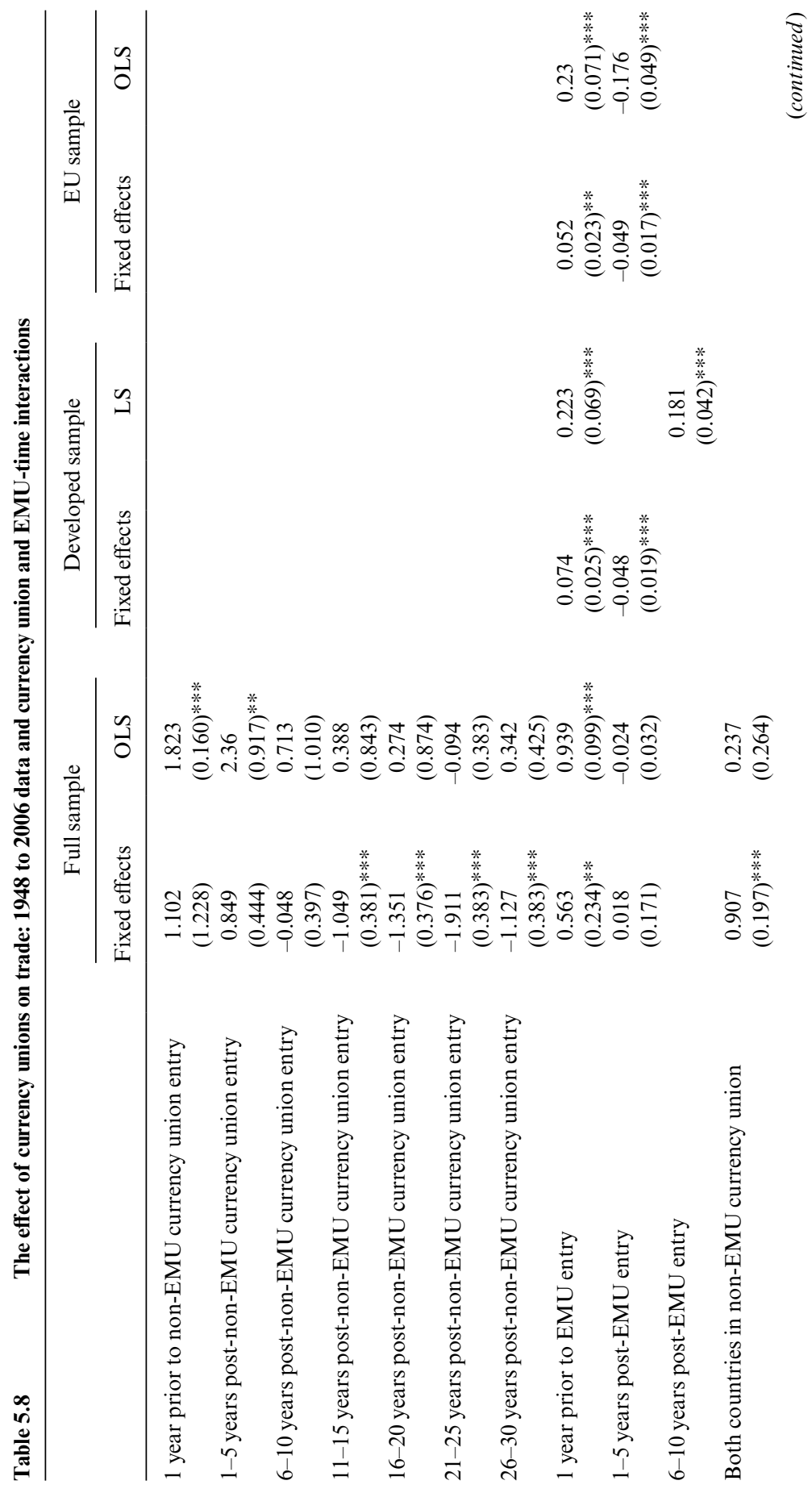




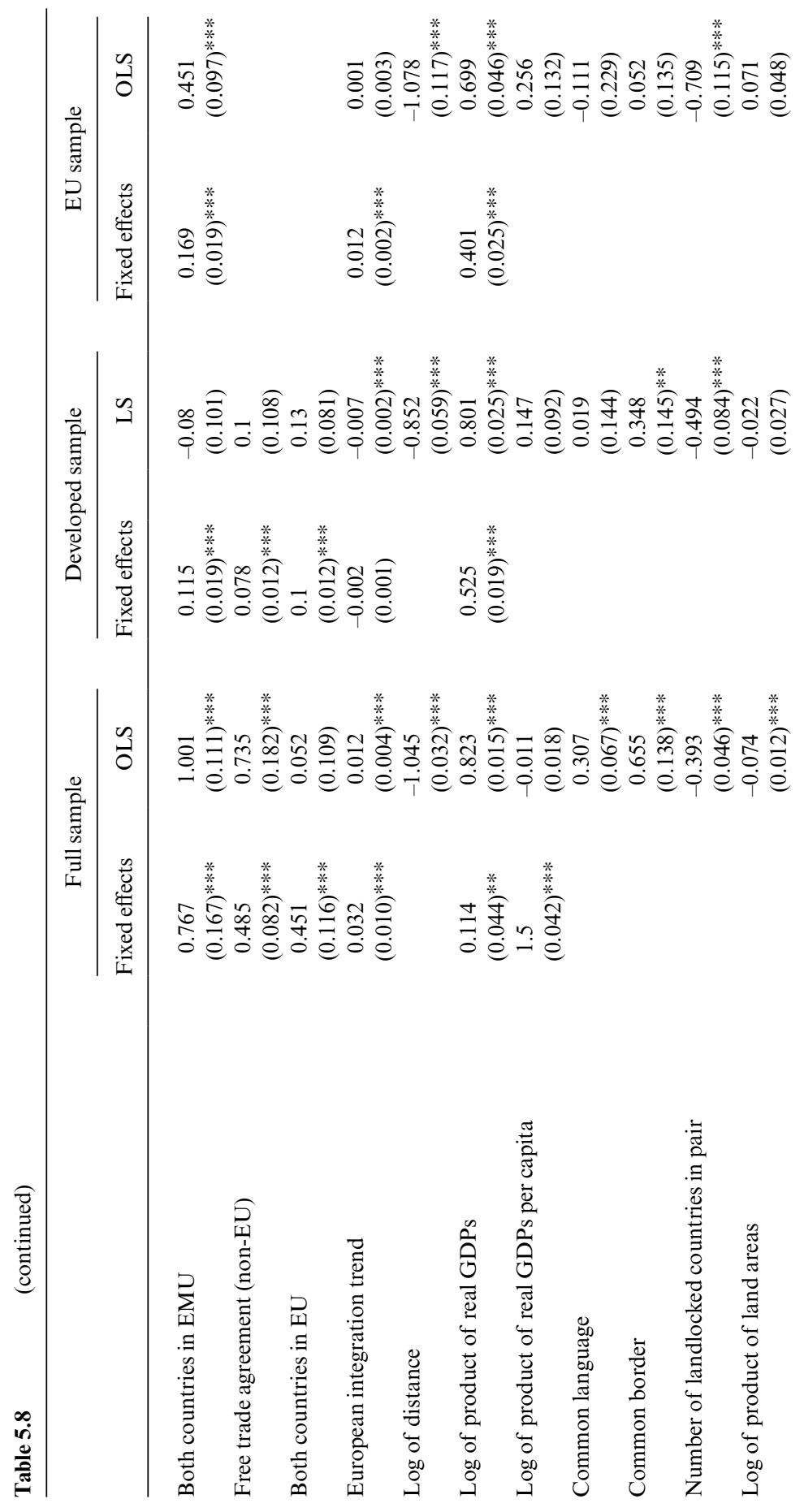




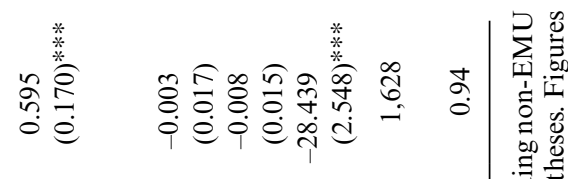

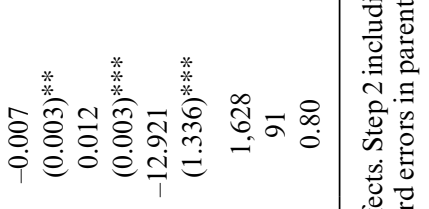

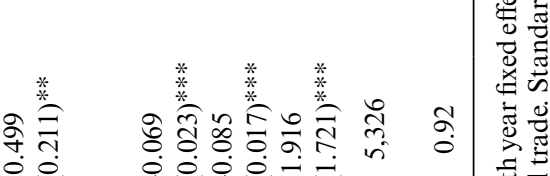

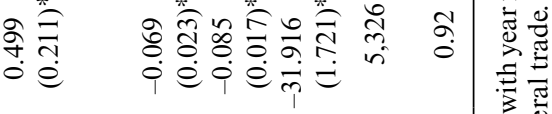

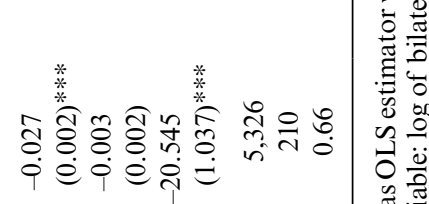

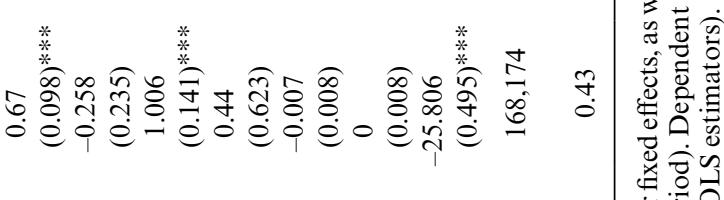

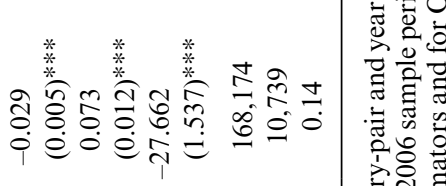

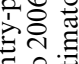

$$
\begin{aligned}
& \text { 응 }
\end{aligned}
$$

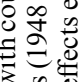

$$
\begin{aligned}
& \text { s. }
\end{aligned}
$$

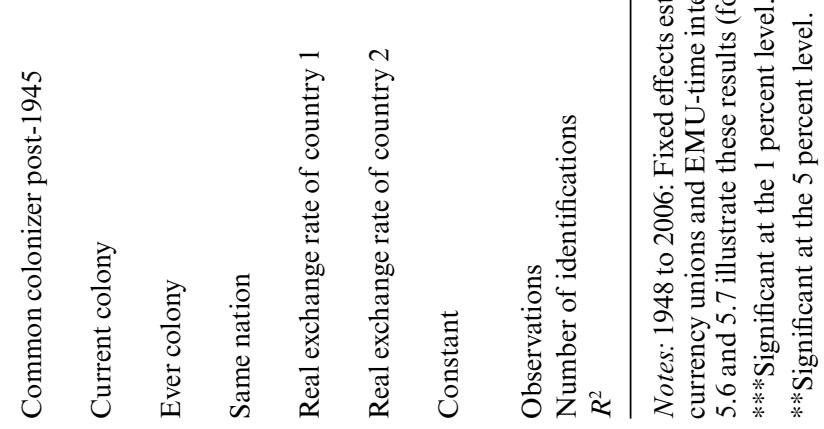




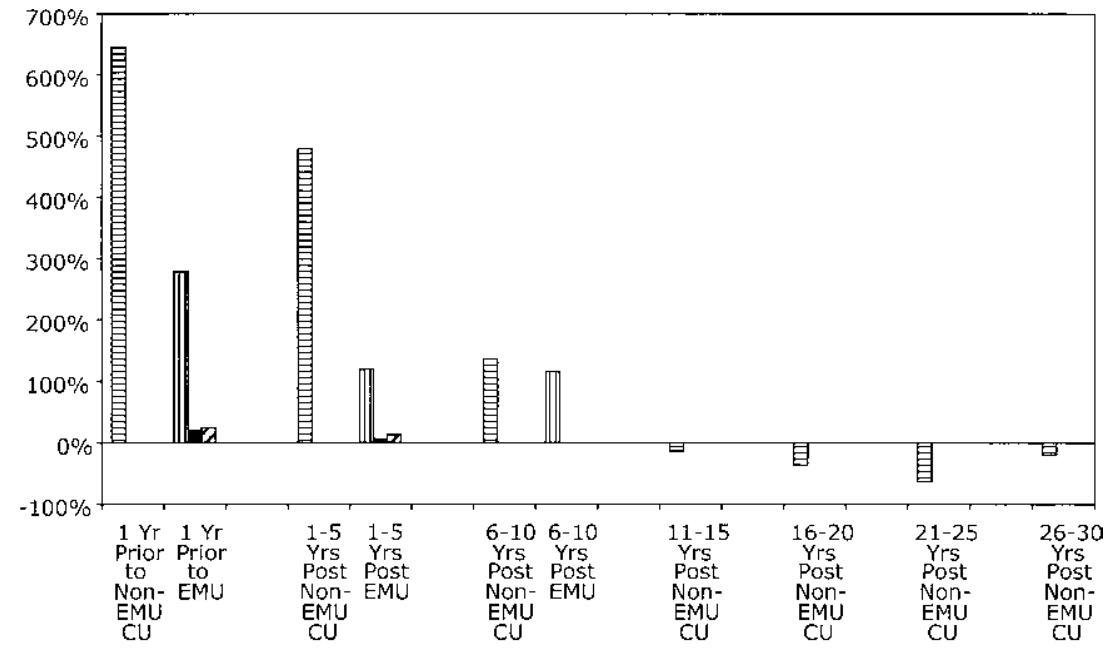

日 Full Sample Estimates $\mathbf{0}$ Full Sample Fixed Developed Sample Fixed EU Sample Fixed for non-EMU Currency Effects Estimator Effects Estimator Effects Estmator Union Interactions

Fig. 5.6 The effect of non-EMU currency unions and of EMU on bilateral trade over time: Fixed effects estimators

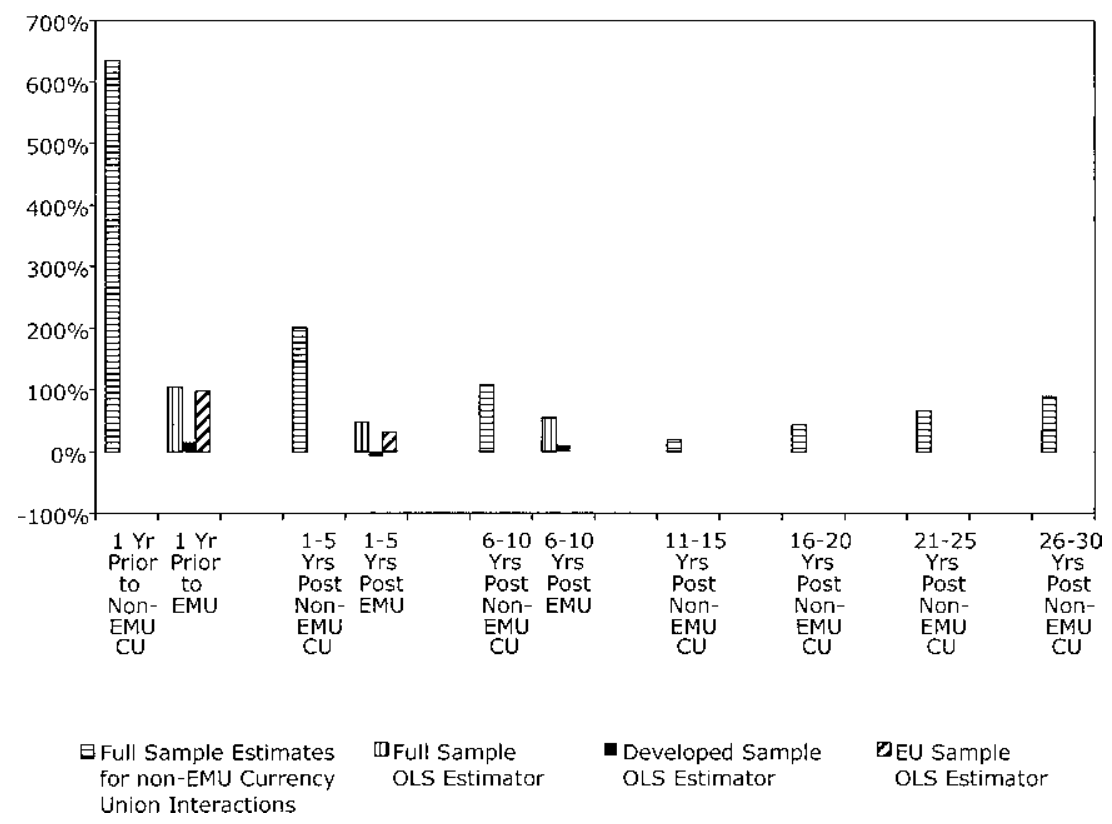

Fig. 5.7 The effect of non-EMU currency unions and of EMU on bilateral trade over time: OLS estimators 
simple OLS results. Under fixed effects, the impact of currency unions continues to decline after ten years (and in fact appears to go negative). Perhaps this has something to do with decreasing effects of colonial legacies. When using OLS instead of fixed effects, the estimated effects remain positive throughout the period (but fail to be significant and even at the thirty-year mark do not rise above the effect in the first ten years). We have not thought of a reason for this discrepancy. But there is no evidence here that any of the observed euro-noneuro discrepancy in estimates is due to lags.

\subsection{A Natural Experiment to Isolate Causality}

The problem of endogeneity is probably the most serious stumbling block in interpreting the Rose findings as a causal relationship between the currency decision and trade patterns. Even when one controls for many other determinants of bilateral trade-geographic, historical, linguistic-one can't escape entirely from the concern that there are missing variables that determine bilateral trade and that the currency regime decision in turn reacts to trade rather than the other way around. The OLS results reported in the previous section may give cause for worry that the high correlations in the year before monetary union and in the five years after are due to reverse causality - that the Eastern Caribbean countries form a currency union because their trade with each other is increasing rather than the other way around. ${ }^{21}$

One way to address the causality problem is with before-and-after case studies. There are a few uniobservational case studies. One example is the case of Ireland. Thom and Walsh (2002) focus on Ireland's abandonment of the pound sterling in 1979; Dwane, Lane, and McIndoe (2006) include also Ireland's adoption of the euro in 1999. There are strong trends in the share of Irish trade, away from the United Kingdom and toward euroland. But it is not possible statistically to discern effects of the two currency changes independently of the effects of Ireland's earlier accession to the European Commission or of the longer-term trend. ${ }^{22}$

Another example is the Czech-Slovak breakup of 1993, which had a substantial negative effect on bilateral trade. ${ }^{23}$ It is viewed as more supportive of the Rose effect, apparently because a customs union was retained. But we know that political borders such as the one that divided the new Czech and

21. I have a harder time, however, seeing how such reverse causality could explain the results with fixed effects or the Glick-Rose estimates.

22. The case examined is potentially one of the more important ones, as Ireland is one of the largest countries in the sample of countries that entered or left a currency union in the period between the 1960s and 1999. But the lack of statistically significant findings is probably to be expected, given the other ongoing developments and the very small number of data points.

23. Frankel (1997, 121-2); Fidrmuc, Horvath, and Fidrmuc (1999); Fidrmuc and Fidrmuc (2001). 
Slovak Republics at the same time that the two adopted separate currencies have effects at least as large as conventional trade barriers.

As noted, Glick and Rose (2002) put together a huge data set covering the entire postwar period, which includes enough additional examples such as the breaking of the Irish-pound link and the Czech-Slovak link to get statistical significance out of the time series dimension. Indeed, they are able to do so even when including pair-specific dummies, thereby giving up the power in the cross-sectional variation. The beauty of fixed effects is indeed that they take account of time-invariant facts, observed or unobserved; so, Glick and Rose's still-significant results are very persuasive. As usual, the authors try lots of robustness checks. This might have been enough to satisfy the hard-line skeptics. ${ }^{24}$

But it was not. For one thing, most of the Glick and Rose results are not only from small countries but also from instances of currency unions breaking up rather than forming, so one cannot be sure that they apply equally to an example of large countries uniting in a currency union. For another thing, the decision to join a currency union, including the decision by Ireland or Slovenia to join EMU, could be misleadingly correlated with a shift in trade patterns toward continental Europe, either because (a) such a shift is a political goal, encouraged by other means as well, or (b) trade is shifting in this direction for natural economic reasons, and policymakers want to reduce foreign exchange costs for importers and exporters.

It would be useful to try some more real-time experiments. A useful comparison would be among the Nordic countries: Finland (which joined the euro along with the European Union while suffering an exogenous loss of trade with the Soviet Union after 1990), Sweden (which joined the European Union but not the euro) and Norway (which has joined neither). But even if these interesting experiments were to produce the finding that the euro joiners experienced increased bilateral trade with euroland relative to the others, the critics could still plausibly claim endogeneity. Perhaps Finland joined the euro as a result of stronger political commitments to European integration than the others had, and perhaps this commitment is reflected in other tradereallocating forces that are not the causal result of the euro itself. Another useful experiment would be to compare those Central and Eastern European countries that have chosen to tie their currencies rigidly to the euro, such as Estonia, with those who have opted for flexibility, such as the Czech Republic. It might also be interesting to look at the case of Switzerland, the one country in the heart of Europe never to join the European Union or EMU, despite sharing borders and languages with four countries.

24. I don't agree with the admonishment (e.g., Tenreyro 2001) that they should try all the robustness checks at the same time rather than one by one. One by one is the way to keep the volume of output manageable. Furthermore, I don't see as interesting an algorithm that checks whether trying every possible permutation can eventually produce some equation in which the currency union coefficient loses significance. 
We here propose a sort of natural experiment designed to be as immune as possible from this sort of endogeneity argument. The experiment is the effect on bilateral trade of African CFA members of the French franc's 1999 conversion to the euro. The long-time link of CFA currencies to the French franc has clearly always had a political motivation. So, CFA trade with France in the past could not reliably be attributed to the currency link, perhaps even after controlling for common language and former colonial status. But with the advent of the euro, fourteen CFA countries woke up in the morning and suddenly found themselves with the same currency link to Germany, Austria, Finland, Portugal, and so forth as they had with France. There was no economic/political motivation on the part of the African countries that led them to an arrangement whereby they were tied to these other European currencies. Thus, if CFA trade with these other European countries has risen, that suggests a euro effect that we can declare causal.

Table 5.9 reports results. The dummy variable representing when one partner is a CFA country and the other is a euro country has a highly significant coefficient of 0.57 . Taking the exponent, the point estimate is that the euro boosted bilateral trade between the relevant African and European countries by 76 percent. Table 5.10 looks at the effects over time. The apparent timing of the effect is partly supportive, though only partly. Its gradual rise during the 1980s and then loss of significance after 1991 matches the contemporaneous progress of European monetary integration and the abrupt crisis in the exchange rate mechanism (ERM) in 1992. The somewhat stronger trade results that begin again in 1997 match well the pattern of the final implementation of EMU that we saw among the euro countries themselves. The estimated effect in 1999 is a big 96 percent. ${ }^{25}$ The puzzle is the loss of significance in the last two years of the sample, 2005 to 2006.

The version of the CFA experiment reported in tables 5.9 and 5.10 does not control for distance. Distance is a relatively poor proxy for transport costs in the case of Africa, because the exports and imports of many of the countries have to travel routes overland to the nearest port and then by sea around the continent, routes that are far longer than indicated distance as the crow flies. For example, Mali, Niger, and Chad (all three of them members of the CFA zone) are as close to the center of the euro zone as the corners of the euro zone are to each other, and yet their actual transport distances to Europe are high.

We have also tried the CFA natural experiment with the usual control for distance. The results for the case where all the other variables are retained are reported elsewhere. ${ }^{26}$ The overall pattern is the same as without distance with respect to time pattern and significance, but the estimated magnitudes are somewhat lower: the coefficient on the dummy representing trade between

25. $\operatorname{Exp}(0.508+0.165)=1.9601$.

26. See tables $8 \mathrm{a}$ and $8 \mathrm{~b}$ of Frankel (2009). 
Table 5.9

CFA natural experiment: The impact of EMU on bilateral trade between CFA and EMU members with year interactions, 1948 to 2006

Dependent variable

Log of bilateral trade

Currency union

$1.706^{* * * *}$

$(0.385)$

EMU

$0.917 * * *$

$(0.132)$

Both countries in European Union

$-0.275$

$(0.206)$

Both countries in CFA franc area (West and Central African)

$-0.731^{*}$

$(0.438)$

One country in CFA franc area, the other in EMU

$0.572 * * *$

$(0.119)$

Log of product of real GDPs

$0.812 * * *$

$(0.016)$

Log of product of real GDPs per capita

$-0.026$

$(0.019)$

Common language

$0.355^{* * *}$

$(0.073)$

Common land border

$2.507 * * *$

$(0.134)$

Free trade agreement

$1.951 * * *$

$(0.181)$

Landlocked

$-0.265^{* * *}$

$(0.049)$

Log of product of land areas

$-0.106 * * *$

$(0.012)$

Common colonizer post-1945

$0.765 * * *$

$(0.106)$

Currently in colonial relationship

$-0.527 * *$

$(0.230)$

Ever in colonial relationship

$1.036^{* * * *}$

$(0.151)$

Same nation/perennial colonies

0.462

$(0.431)$

$-0.002$

$(0.008)$

$-0.004$

$(0.008)$

Real exchange rate of country 2

Constant

(0.456)

Observations

169,561

$R^{2}$

0.40

Note: 1948 to 2006: OLS estimator with year fixed effects. Robust standard errors in parentheses, clustered on country-pairs.

***Significant at the 1 percent level.

**Significant at the 5 percent level.

*Significant at the 10 percent level. 
Dependent variable

Currency union

EMU

Both countries in European Union

Both countries in CFA franc area (West and Central African)

One country in CFA franc area, the other in EMU

One country in CFA, one country in EMU $\times 1980$

One country in CFA, one country in EMU $\times 1981$

One country in CFA, one country in EMU $\times 1982$

One country in CFA, one country in EMU $\times 1983$

One country in CFA, one country in EMU $\times 1984$

One country in CFA, one country in EMU $\times 1985$

One country in CFA, one country in EMU $\times 1986$

One country in CFA, one country in EMU $\times 1987$

One country in CFA, one country in EMU $\times 1988$

One country in CFA, one country in EMU $\times 1989$

One country in CFA, one country in EMU $\times 1990$

One country in CFA, one country in EMU $\times 1991$

One country in CFA, one country in EMU $\times 1992$

One country in CFA, one country in EMU $\times 1993$

One country in CFA, one country in EMU × 1994

One country in CFA, one country in EMU $\times 1995$

One country in CFA, one country in EMU $\times 1996$

One country in CFA, one country in EMU $\times 1997$

One country in CFA, one country in EMU $\times 1998$

One country in CFA, one country in EMU × 1999

Log of bilateral trade

$1.710^{* * *}$

(0.386)

$0.229 *$

$(0.138)$

$-0.137$

$(0.211)$

$-0.726^{*}$

$(0.439)$

0.165

(0.241)

0.144

(0.094)

(dropped)

0.024

(0.082)

0.184 *

(0.097)

0.324 **

(0.130)

$0.345^{* * * *}$

(0.121)

$0.437^{* * *}$

(0.135)

$0.414^{* * *}$

(0.151)

$0.467^{* * *}$

(0.141)

$0.313^{* *}$

(0.151)

0.234

(0.160)

$0.350^{*}$

(0.182)

0.221

(0.159)

0.186

(0.164)

0.066

$(0.163)$

0.237

(0.166)

0.079

(0.158)

0.640 ***

$(0.226)$

0.549 **

$(0.222)$

0.508 **

(0.222) 
One country in CFA, one country in EMU $\times 2000$

$0.450^{* *}$

(0.223)

One country in CFA, one country in EMU $\times 2001$

$0.546^{* *}$

$(0.223)$

One country in CFA, one country in EMU $\times 2002$

$0.519 * *$

(0.226)

One country in CFA, one country in EMU $\times 2003$

$0.428 *$

(0.233)

One country in CFA, one country in EMU $\times 2004$

$0.437 *$

$(0.235)$

One country in CFA, one country in EMU $\times 2005$

0.22

(0.238)

One country in CFA, one country in EMU $\times 2006$

0.178

(0.246)

Log of product of real GDPs

$0.813^{* * *}$

Log of product of real GDPs per capita

(0.016)

$-0.027$

$(0.019)$

Common language

$0.358 * * *$

(0.073)

Common land border

$2.515^{* * *}$

(0.134)

Free trade agreement

$1.940 * * *$

Landlocked

(0.182)

$-0.267 * * *$

(0.049)

Log of product of land areas

$-0.107 * * *$

(0.012)

Common colonizer post-1945

$0.770 * * *$

(0.106)

Currently in colonial relationship

$-0.493^{* *}$

(0.229)

Ever in colonial relationship

$1.004 * * *$

(0.149)

Same nation/perennial colonies

0.46

(0.433)

$-0.003$

(0.008)

$-0.006$

(0.008)

Constant

$-34.094^{* * *}$

(0.457)

Observations

169,561

$R^{2}$

0.40

Note: 1948 to 2006: OLS estimator with year fixed effects. Robust standard errors in parentheses. Dummy for CFA-EMU country-pairs takes on value 1 from 1999 onward.

***Significant at the 1 percent level.

**Significant at the 5 percent level.

* Significant at the 10 percent level. 
CFA members and euro members again rises during the 1980s, loses significance in 1992 (the year of the ERM crisis), comes roaring back with a highly significant 0.78 in 1997 (two years before the first EMU year), stays strong through 2004, and then puzzlingly loses significance in 2005 to 2006. In 1999, CFA countries trade with euro countries an extra 47 percent more than otherwise similar pairs of countries. ${ }^{27}$

The list of explanatory variables has grown rather long. The author has never been very fond of the real exchange rate variables. Further, the dummy "currently in colonial relationship" seems to offer little, either ex ante or in practice, that is not already covered by the dummy "ever in colonial relationship" together with "same nation/perennial colonies." In view of multicollinearity concerns, all three variables are dropped in the final tables reported in this chapter. In table 5.11, the dummy variable representing when one partner is a CFA country and the other is a euro country has a highly significant coefficient of 0.38 . Taking the exponent, the point estimate is that the euro boosted bilateral trade between the relevant African and European countries by 46 percent. Table 5.12 looks at the effects over time. The apparent timing of the effect coincides better with the advent of full EMU than before: it is not significant in the 1980s, but as before, it attains in 1997 to 2004 a highly significant effect that is in the vicinity of 50 percent. ${ }^{28}$ The puzzle of lost significance in 2005 to 2006 remains.

Overall, it is striking that this natural experiment produces such strong estimates for the trade effects of an exogenous currency link. Evidently, the findings of strong effects from currency links among small countries cannot be entirely attributed to the endogeneity of the decision to form a monetary union.

\subsection{Conclusion}

This chapter seeks to explain the discrepancy between estimates of the euro's effect on trade among members - about 15 percent in our results, as in those of earlier authors - and estimates of the effects of other earlier currency unions in large samples of countries - on the order of 200 percent. It examines three obvious suspects. First are lags. The euro is still very young. We do find an upward trend in the trade effect during 1999 to 2004, but surprisingly, we find no tendency during 2005 to 2006 for the euro's effect to have risen above the level that it had attained by 2004 (15 percent). Second is size. The European countries are much bigger than most of those who had formed currency unions in the past. But the effect of a currency union does not appear to diminish discernibly with country size. Third is

27. $\operatorname{Exp}(0.623-0.241)=1.4652$.

28. In $1999, \exp (0.623-0.241)=1.47$. It is also worth noting that the effect on trade between two CFA members is not significantly less than for pairs that belong to other currency unions. 
Table 5.11

CFA natural experiment: The impact of EMU on bilateral trade between CFA and EMU members with year interactions, 1948 to 2006 (with distance but without real exchange rates)

Dependent variable

Log of bilateral trade

Currency union

$0.547^{*}$

$(0.300)$

EMU

$1.198 * * *$

$(0.101)$

Both countries in European Union

$-0.535^{* * *}$

$(0.195)$

Both countries in CFA franc area (West and Central African)

$-0.268$

$(0.398)$

One country in CFA franc area, the other in EMU

$0.381^{* * *}$

$(0.108)$

Log of product of real GDPs

$0.769^{* * *}$

$(0.015)$

Log of product of real GDPs per capita

0.015

$(0.018)$

Log of distance

$-0.964 * * *$

$(0.035)$

Common language

$0.203^{* * *}$

$(0.069)$

Common land border

$0.616^{* * *}$

$(0.154)$

Free trade agreement

$0.617 * * *$

$(0.180)$

Landlocked

$-0.491^{* * *}$

(0.048)

Log of product of land areas

$-0.082 * * *$

$(0.012)$

Common colonizer post-1945

$0.566^{* * * *}$

$(0.106)$

Ever in colonial relationship

$0.771^{* * *}$

$(0.151)$

Same nation/perennial colonies

(3.259)

Constant

Observations

294,182

$R^{2}$

0.38

Note: 1948 to 2006: OLS estimator with year fixed effects. Robust standard errors in parentheses, clustered on country-pairs.

***Significant at the 1 percent level.

*Significant at the 10 percent level. 
Dependent variable

Log of bilateral trade

Currency union

$0.553^{*}$

$(0.301)$

EMU

$-0.049$

$(0.241)$

Both countries in European Union

$-0.191$

$(0.234)$

Both countries in CFA franc area (West and Central African)

$-0.274$

(0.398)

One country in CFA franc area, the other in EMU

$-0.111$

$(0.300)$

One country in CFA, one country in EMU $\times 1980$

0.152

$(0.315)$

One country in CFA, one country in EMU $\times 1981$

0.114

$(0.287)$

One country in CFA, one country in EMU $\times 1982$

0.049

$(0.279)$

One country in CFA, one country in EMU $\times 1983$

0.208

$(0.284)$

One country in CFA, one country in EMU $\times 1984$

0.359

$(0.286)$

One country in CFA, one country in EMU $\times 1985$

0.316

$(0.290)$

One country in CFA, one country in EMU $\times 1986$

0.42

$(0.309)$

One country in CFA, one country in EMU $\times 1987$

0.334

$(0.297)$

One country in CFA, one country in EMU $\times 1988$

0.402

$(0.332)$

One country in CFA, one country in EMU $\times 1989$

0.203

$(0.337)$

One country in CFA, one country in EMU $\times 1990$

$-0.032$

$(0.326)$

One country in CFA, one country in EMU $\times 1991$

0.236

$(0.332)$

One country in CFA, one country in EMU × 1992

0.176

$(0.321)$

One country in CFA, one country in EMU × 1993

0.174

$(0.321)$

One country in CFA, one country in EMU $\times 1994$

0.053

$(0.321)$

One country in CFA, one country in EMU × 1995

0.215

$(0.320)$

One country in CFA, one country in EMU $\times 1996$

0.073

$(0.320)$

One country in CFA, one country in EMU $\times 1997$

$0.683^{* *}$

$(0.306)$

One country in CFA, one country in EMU $\times 1998$

$0.626^{* *}$

$(0.304)$

(continued) 
One country in CFA, one country in EMU $\times 1999$

One country in CFA, one country in EMU $\times 2000$

One country in CFA, one country in EMU $\times 2004$

One country in CFA, one country in EMU × 2005

One country in CFA, one country in EMU $\times 2006$

Log of product of real GDPs

Log of product of real GDPs per capita

Log of distance

Common language

Common land border

Free trade agreement

Landlocked

$(0.180)$

$-0.489^{* * *}$

(0.048)

Log of product of land areas

Common colonizer post-1945

Ever in colonial relationship

Same nation/perennial colonies

Constant

Observations

Note: 1948 to 2006: OLS estimator with year fixed effects. Robust standard errors in parentheses.

***Significant at the 1 percent level.

**Significant at the 5 percent level.

*Significant at the 10 percent level. 
the endogeneity of the decision to adopt an institutional currency link. Perhaps the high correlations estimated in earlier studies were spurious, an artifact of reverse causality. But we examine the natural experiment of trade between CFA countries and (non-Francophone) euro members and find a strong switch that in this case is unlikely to be the artifact of an endogenous currency decision. In short, we find no evidence that any of these factors explains any share of the gap, let alone all of it.

What we find instead is a surprising new suspect: results reported here suggest that the discrepancy might stem from sample size. If one estimates the effects of the euro versus other monetary unions in a large sample that includes all countries and all years, thereby bringing to bear as much information as possible on questions such as the proper coefficients on common border and common language in a gravity model, then the effect of the euro in the first eight years appears to be large, even comparable with the effect of the other noneuro monetary unions. It is hard to believe, however, that the true effect of the euro has indeed been this large; if intraeuroland trade had doubled or tripled since 1999, we would see it in the raw data and would not need to run a regression. Perhaps it is best to summarize the conclusions of the chapter by saying that each of the three obvious suspects - lags, size, and endogeneity — has an apparent alibi, but the true perpetrator remains at large.

\section{References}

Allington, N. F. B., P. Kattuman, and F. Waldmann. 2005. One money, one market, one price. International Journal of Central Banking 1 (3): 73-115.

Anderson, J. and E. van Wincoop. 2001. Gravity with gravitas: A solution to the border puzzle. NBER Working Paper no. 8079. Cambridge, MA: National Bureau of Economic Research, January.

Anderson, K., and H. Norheim. 1993. History, geography and regional economic integration. In Regionalism and the global trading system, ed. K. Anderson and R. Blackburst. London: Harvester Wheatsheaf.

Baldwin, R. 2006. The euro's trade effects. ECB Working Paper no. 594 Frankfurt: European Central Bank.

Begg, D., O. Blanchard, D. Coyle, B. Eichengreen, J. Frankel, F. Giavazzi, R. Portes, et al. 2003. The consequences of saying no: An independent report into the economic consequences of the UK saying no to the euro. London: Commission on the United Kingdom Outside the Euro.

Berger, H., and V. Nitsch. 2005. Zooming out: The trade effect of the euro in historical perspective. CESifo Working Paper no. 1435. Munich: Munich Society for the Promotion of Economic Research.

Brada, J., and J. Mendez. 1985. Economic integration among developed, developing and centrally planned economies: A comparative analysis. Review of Economics and Statistics 67 (4): 549-56.

Bun, M., and F. Klaassen. 2002. Has the euro increased trade? TI Discussion Paper 
no. 2002-108/2. Amsterdam: Tinbergen Institute. Available at: http://www.eabcn .org/research/documents/bun_klaasen02.pdf.

Chintrakarn, P. 2008. Estimating the euro effects on trade with propensity score matching. Review of International Economics 16 (1): 186-98.

De Grauwe, Paul. 1988. Exchange rate variability and the slowdown in growth of international trade. IMF Staff Papers 35:63-84.

De Nardis, S., and C. Vicarelli. 2003. Currency unions and trade: The special case of EMU. World Review of Economics 139 (4): 625-49.

Dwane, C., P. Lane, and T. McIndoe. 2006. Currency unions and Irish external trade. IIIS Discussion Paper no. 189. Dublin: Institute for International Integration Studies, Trinity College.

Eichengreen, B., and D. Irwin. 1998. The role of history in bilateral trade flows. In The regionalization of the world economy, ed. J. Frankel, 33-62. Chicago: University of Chicago Press.

Engel, C., and J. Rogers. 2004. European product market integration after the euro. Economic Policy 19 (39) : 347-84.

Fidrmuc, J., and J. Fidrmuc. 2001. Disintegration and trade. LICOS Discussion Paper no. 9901. Catholic University of Leuven, LICOS Center for Institutions and Economic Performance.

Fidrmuc, J., J. Horvath, and J. Fidrmuc. 1999. The stability of monetary unions: Lessons from the breakup of Czechoslovakia. Journal of Comparative Economics 27 (4): 752-81.

Flam, H., and H. Nordström. 2003. Trade volume effects of the euro: Aggregate and sector estimates. Stockholm University, IIES Seminar Paper no. 746. Institute for International Economic Studies.

Frankel, J. 1997. Regional trading blocs in the world trading system. Washington, DC: Institute for International Economics.

2003. The UK decision re EMU: Implications of currency blocs for trade and business cycle correlations. In Submissions on EMU from leading academics, ed. Her Majesty's Treasury, 93-105. London: Her Majesty's Stationery Office.

- 2005. Real convergence and euro adoption in Central and Eastern Europe: Trade and business cycle correlations as endogenous criteria for joining EMU. In Euro adoption in Central and Eastern Europe: Opportunities and challenges, ed. S. Schadler, 9-22. Washington, DC: International Monetary Fund.

- 2009. The estimated trade effects of the euro: Why are they below those from historical monetary unions among smaller countries? Working Paper no. 20090008. Harvard University, Weatherhead Center for International Affairs, April.

Frankel, J., and A. Rose. 2002. An estimate of the effect of common currencies on trade and income. Quarterly Journal of Economics 117 (2): 437-66.

Frankel, J., and S.-J. Wei. 1993. Trade blocs and currency blocs. NBER Working Paper no. 4335. Cambridge, MA: National Bureau of Economic Research, April.

1995a. Emerging currency blocs. In The international monetary system: Its institutions and its future, ed. H. Genberg, 111-43. Berlin: Springer.

- 1995b. European integration and the regionalization of world trade and currencies: The economics and the politics. In Monetary and fiscal policy in an integrated europe, ed. B. Eichengreen, J. Frieden, and J. von Hagen, 202-31. Heidelberg: Springer-Verlag.

1997. Regionalization of world trade and currencies: Economics and politics. In The regionalization of the world economy, ed. J. Frankel, 189-226. Chicago: University of Chicago Press.

Glick, R., and A. Rose. 2002. Does a currency union affect trade? The time-series evidence. European Economic Review 46 (6): 1125-51. 
Goldberg, P. K., and F. Verboven. 2001. Market integration and convergence to the law of one price: Evidence from the European car market. NBER Working Paper no. 8402. Cambridge, MA: National Bureau of Economic Research, July.

2004. Cross-country price dispersion in the euro era: A case study of the European car market. Economic Policy 19 (40): 483-521.

Hamilton, C., and L. A. Winters. 1992. Opening up international trade in Eastern Europe. Economic Policy 7 (14): 77-116.

Helliwell, J. 1998. How much do national borders matter? Washington, DC: Brookings Institution Press.

Kleiman, E. 1976. Trade and the decline of colonialism. Economic Journal 86 (343): 459-80.

Klein, M. 2002. Dollarization and trade. NBER Working Paper no. 8879. Cambridge, MA: National Bureau of Economic Research, April.

Klein, M., and J. C. Shambaugh. 2006. Fixed exchange rates and trade. Journal of International Economics 70 (2): 359-83.

McCallum, J. 1995. National borders matter: Canada-U.S. regional trade patterns. American Economic Review 85 (3): 615-23.

McKinnon, R. 1963. Optimum currency areas. American Economic Review 53 (4): 717-24.

Melitz, J. 2001. Geography, trade and currency union. CEPR Discussion Paper no. 2987. London: Center for Economic Policy Research.

Micco, A., E. Stein, and G. Ordoñez. 2002. Should the UK join EMU? Washington, DC: Inter-American Development Bank.

2003. The currency union effect on trade: Early evidence from EMU. Economic Policy 18 (37): 315-43.

Nitsch, V. 1991. National borders and international trade: Evidence from the European Union. Berlin: Bankgesellschaft.

2000. National borders and international trade: Evidence from the European Union. Canadian Journal of Economics 33 (4): 1091-105.

. 2001. Honey, I shrunk the currency union effect on trade. Berlin: Bankgesellschaft.

Pakko, M. R., and H. J. Wall. 2001. Reconsidering the trade-creating effects of a currency union. Federal Reserve Board of St. Louis Review 83 (5): 37-46.

Parsley, D., and S.-J. Wei. 2001. Limiting currency volatility to stimulate goods market integration: A price based approach. NBER Working Paper no. 8468. Cambridge, MA: National Bureau of Economic Research, September.

Persson, T. 2001. Currency unions and trade: How large is the treatment effect? Economic Policy 16 (33): 435-48.

Rogers, J. H. 2001. Price level convergence, relative prices, and inflation in Europe. International Finance Discussion Paper no. 699. Washington, DC: Board of Governors of the Federal Reserve System.

. 2002. Monetary union, price level convergence, and inflation: How close is Europe to the United States? International Finance Discussion Paper no. 740. Washington, DC: Board of Governors of the Federal Reserve System.

Rose, A. 2000. One money, one market: Estimating the effect of common currencies on trade. Economic Policy 15 (30): 7-45.

2001. Currency unions and trade: The effect is large. Economic Policy 16 (33): 449-61.

2004. A meta-analysis of the effect of common currencies on international trade. NBER Working Paper no. 10373. Cambridge, MA: National Bureau of Economic Research, March.

Rose, A. K., and E. van Wincoop. 2001. National money as a barrier to trade: The real case for monetary union. American Economic Review 91 (2): 386-90. 
Tenreyro, S. 2001. On the causes and consequences of currency unions. Harvard University, Department of Economics. Manuscript, November.

Thom, R., and B. Walsh. 2002. The effect of a common currency on trade: Ireland before and after the sterling link. European Economic Review 46 (6): 1111-23.

Thursby, J. G., and M. C. Thursby. 1987. Bilateral trade flows, the Linder hypothesis, and exchange risk. Review of Economics and Statistics 69 (3): 488-95.

Wang, Z. K., and L. A. Winters. 1991. The trading potential of Eastern Europe. CEPR Discussion Paper no. 610. London: Center for Economic Policy Research.

Wei, S.-J. 1996. Intra-national versus international trade: How stubborn are nations in global integration? NBER Working Paper no. 5531. Cambridge, MA: National Bureau of Economic Research, April.

\section{Comment Silvana Tenreyro}

\section{Background and Summary}

In an influential and provocative paper, Andy Rose (2000) reported that sharing a common currency enhanced bilateral trade by more than 200 percent. ${ }^{1}$ The paper divided the profession into two camps: believers and skeptics. The latter doubted the plausibility of such a large trade effect and pointed out the futility of attempting to extrapolate the postwar experience of currency unions (made mostly of small and poor countries) to countries adopting the euro. Subsequent work by Micco, Stein, and Ordoñez (2003) using data on the early years of the euro found that the effect of the euro on bilateral trade between euro zone countries ranged from 4 to 10 percent when compared to trade between all other pairs of countries and from 8 to 16 percent when compared to trade among noneuro zone countries.

As the euro marks its tenth anniversary, Frankel's chapter provides a timely opportunity to explain the gap between Rose's and Micco, Stein, and Ordoñez's estimates and to reappraise the effect of the euro on trade.

The chapter argues that the gap between estimates is not caused by any of the usual suspects. In particular, the difference is not caused by (a) lags (or the view that it takes time for currency unions to affect trade patterns); (b) omitted variables (including the Anderson and Van Wincoop multilateral resistance term); ${ }^{2}$ (c) reverse causality (trade may lead to the formation of currency unions); or (d) threshold effects (or the view that currency unions can cause large trade increases in countries that are below a certain size or income threshold). Instead, the chapter concludes that the culprit for the difference in estimates is sample size. Indeed, Micco, Stein, and Ordoñez (2003) estimated the euro effect using only post-1992 data. When the whole sample (with all country pairs, going back to the mid-1940s) is used, Fran-

Silvana Tenreyro is a reader in economics at the London School of Economics.

1. With some exceptions, work by other scholars found confirmatory results using postwar data. See early review in Alesina, Barro, and Tenreyro (2002) and Baldwin (2006).

2. See Anderson and Van Wincoop (2002). 